\title{
Model-simulated interannual variability of Lake Erie ice cover, circulation, and thermal structure in response to atmospheric forcing, 2003-2012
}

\author{
Ayumi Fujisaki, ${ }^{1}$ Jia Wang, ${ }^{2}$ Xuezhi Bai, ${ }^{1}$ George Leshkevich, ${ }^{2}$ and Brent Lofgren ${ }^{2}$ \\ Received 10 January 2013; revised 21 June 2013; accepted 9 July 2013; published 5 September 2013.
}

[1] Interannual variability of ice cover, circulation, and thermal structure in Lake Erie for 2003-2012 was investigated using a three-dimensional hydrodynamic model coupled with ice processes. The model reproduced minima of ice extent in the winters of 2006 and 2012 (mild winters), as well as maxima in 2009 and 2011 (severe winters) in agreement with the observational analysis. The model reasonably captured ice thicknesses, seasonal variation of the mean surface temperature, and lake circulation. The model results showed early onset of stratification in March after the almost ice-free winter of 2012. In the mild winters, the coastal current speed was significantly higher than the 9 year mean, since the larger open water region due to less ice cover allowed the more effective wind driven circulation. In the severe winters, the lake circulation was slowed because the packed ice reduced wind stress on the water surface. Seasonal means of coastal current speed ranged from $3.9 \mathrm{~cm} / \mathrm{s}$ in the severe winter (January to March mean) of 2009 to $7.2 \mathrm{~cm} / \mathrm{s}$ in the mild winter of 2012 . The variation was much larger than in the other seasons $( \pm 0.6 \mathrm{~cm} / \mathrm{s})$. The results imply that decreasing ice cover could lead to a more energetic coastal circulation in winter, which could influence lake turbidity, material transport, and nearshore waves. Finally, the interannual variation of ice cover is discussed in relation to teleconnection patterns. The ice minimum (maximum) in the winter of 2006 (2009) can be explained by the intermittent positive (negative) North Atlantic Oscillation that occurred in January (December to January).

Citation: Fujisaki, A., J. Wang, X. Bai, G. Leshkevich, and B. Lofgren (2013), Model-simulated interannual variability of Lake Erie ice cover, circulation, and thermal structure in response to atmospheric forcing, 2003-2012, J. Geophys. Res. Oceans, 118, 4286-4304, doi:10.1002/jgrc.20312.

\section{Introduction}

[2] It is important to understand physical responses of large lakes in the cold regions to interannual variations in ice cover. In the Laurentian Great Lakes, which are partially covered with ice from December to April, the ice cover significantly influences the regional climate [Assel et al., 2004; Notaro et al., 2013], the lake ecosystem [Vanderploeg et al., 1992; White et al., 2012], and the regional economy [Niimi, 1982].

[3] Ice cover inhibits direct lake-atmosphere interaction and changes the lake thermal structure. In winter, it insulates the water surface from cold air and decreases the sensible and latent heat fluxes [Gerbush et al., 2008]. In early

\footnotetext{
${ }^{1}$ Cooperative Institute for Limnology and Ecosystems Research, University of Michigan, Ann Arbor, Michigan, USA.

${ }^{2}$ NOAA Great Lakes Environmental Research Laboratory, Ann Arbor, Michigan, USA.

Corresponding author: A. Fujisaki, Cooperative Institute for Limnology and Ecosystems Research, University of Michigan, 4840 S. State Rd., Ann Arbor, MI 48108, USA. (ayumif@umich.edu)

(C)2013. American Geophysical Union. All Rights Reserved. 2169-9275/13/10.1002/jgrc.20312
}

spring, ice cover delays warming of the water surface by the solar radiation due to the high surface albedo. Ice cover also influences the lake circulation and vertical mixing. It causes dampening of lake circulation and coastal waves, both of which could influence nearshore ecology as well as movement of nutrient-enriched river water and sediment into pelagic waters [Kerfoot et al., 2011; Luo et al., 2012]. Based on their study in Lake Michigan, Vanderploeg et al. [1992] suggested that an under-ice bloom could occur in winter, when ice was covered with little snow, as the vertical mixing was suppressed by ice cover, and the water below ice was stabilized.

[4] Knowledge of the ice-lake system is also important from economical and industrial perspectives. For example, severe coastal ice may damage shoreline structures [Bolsenga, 1988]. Recent interests in offshore wind power development in the Great Lakes must deal with coastal ice, whose flow and mechanical pressure on offshore turbine structures could cause significant problems.

[5] It has been found that the long-term decline of the ice cover on the Great Lakes is significantly affected by global climate change [Magnuson et al., 2000; Austin and Colman, 2007; Wang et al., 2012a]. The long-term decline in ice cover is likely tied with the physical structure in the 
lakes. For example, Desai et al. [2009] found that surface wind speed and current speeds in Lake Superior have increased since 1985 due to a reduction of the temperature gradient between the air and water that has destabilized the atmospheric surface layer above the lake. They suggest that decreasing ice cover has contributed to the reduction in the air-water temperature gradient by increasing heat input to the lake surface. These previous studies imply that the Great Lakes-ice system has experienced a significant change over the last couple of decades. The circulation and thermal structure of the lakes likely have changed along with the long-term decline of ice cover. However, technical difficulty limits the number of in situ measurements in icecovered lakes, and even the year-to-year responses are not well understood.

[6] It is important to examine the responses of lakes to interannual variations in ice cover, since Great Lakes ice cover has large interannual variation due to the natural variability of climate [Wang et al., 2010a, 2012a; Bai et al., 2011, 2012]. Bai et al. [2012] showed that Great Lakes ice cover is influenced by both the North Atlantic Oscillation (NAO) and El Niño-Southern Oscillation (ENSO): Positive (negative) NAO events tend to cause lower (higher) ice cover. El Niño and strong La Niña events are often associated with lower ice cover, while weak La Niña events are often associated with higher ice cover. They also suggested that the combined effect of a strong positive NAO and La Niña could cause extreme warmth in the Great Lakes region, which can also occur during strong El Niño events (X. Bai, personal communication, 2013).

[7] Several studies have discussed the interannual variability of the Great Lakes ice-lake system, based on satellite-derived ice extent data [Austin and Colman, 2007; Bai et al., 2012; Wang et al., 2012a]. On the other hand, recent studies have incorporated ice cover in Great Lakes hydrodynamics models. Bennington et al. [2010] investigated the general circulation of Lake Superior from 1979 to 2006 using the Massachusetts Institute of Technology (MIT) general ocean circulation model. Their work looked at the presence of ice by modifying the surface fluxes of heat and momentum, as well as evaporation as a function of ice concentration in a cell, using an ice concentration analysis. White et al. [2012] applied a Regional Oceanic Modeling System (ROMS) that includes a dynamic and thermodynamic ice model and a biochemical model to Lake Superior, successfully reproducing the observed longterm warming of lake surface temperature. They showed that the annual gross primary production correlated positively with mean annual temperature and negatively with mean winter ice-cover magnitude. The most recent modeling work that includes ice processes in the Great Lakes used Nucleus for European Modelling of the Ocean (NEMO) along with the model-derived atmospheric forcing and river inputs [Dupont et al., 2012]. The model reproduced the variation of lake levels, ice concentrations, lake thermal structures, and lake currents reasonably. On the other hand, the influences of anomalous ice cover on lake circulation and thermal structure are not well known. Fujisaki et al. [2012] showed that ice cover could significantly dampen the coastal flow in winter due to the ice-water stress coupling, based on a sensitivity study in 2003-2004 using the ice-lake model for Lake Erie. This finding moti- vates us to study the year-to-year variation of the coastal flow in winter in response to ice cover that changes interannually under climate variability.

[8] In relatively warm winters, the larger open water area due to low ice coverage allows wind stress to effectively drive the water circulation, while the packed ice cover in severe winters that limits ice motion reduces wind stress to be transmitted to the water surface through the icewater stress coupling. In addition, fast or slow decay of ice cover would determine the early or late onset of stratification, affecting lake surface temperature from spring to summer, as well as affecting the lake ecosystem. Hence, it is useful to study the physical response of the lakes to interannually varying ice cover.

[9] This study will look at the interannual variability of the ice-lake system in the Great Lakes, focusing on lake circulation and thermal structure in characteristic mild and severe winters with anomalous ice coverage, based on a three-dimensional hydrodynamic model coupled with ice processes. First, we conducted a hindcast from April 2003 to April 2012, whose results are examined in comparison with the available observations of ice extent, lake surface temperature, ice thickness, and lake circulation. Next, the interannual variations of ice production, thermal structure, and lake circulation are discussed, focusing on the mild winters (2005-2006 and 2011-2012) and the severe winters (2008-2009 and 2010-2011). We especially focus on the accelerated coastal flow in the mild winters, and the thermal structure in the unusually warm March of 2012. These characteristic winters are also discussed in conjunction with the large-scale climate events, including NAO and ENSO based on the findings in Bai et al. [2012].

\section{Model}

\subsection{Coupled Lake-Ice Model}

[10] ICEPOM, a three-dimensional hydrostatic ocean model with the Boussinesq approximation based on the Princeton Ocean Model [Mellor et al., 2002], is used for a hindcast from 1 April 2003 to 17 April 2012. The computational domain includes Lake Erie (Figure 1). Depths used in the $2 \mathrm{~km}$ grid are derived from NOAA's three arc second raster bathymetry for Lake Erie (http://www.ngdc.noaa.gov/mgg/greatlakes/erie.html) by averaging values within each $2 \mathrm{~km}$ grid square. The bottom drag coefficient is calculated by assuming a logarithmic bottom boundary layer with a roughness length that varies from $2 \mathrm{~cm}$ in shallow water to $0.1 \mathrm{~cm}$ in deep water (previously a constant $1 \mathrm{~cm}$ in Fujisaki et al. [2012]). A sigma coordinate is used in the vertical direction with 21 levels. The model includes the level 2.5 turbulence closure parameterization [Mellor and Yamada, 1982] with a wave-breaking model as the surface boundary condition [Craig and Banner, 1994]. Horizontal diffusion is calculated with a Smagorinsky eddy diffusion parameterization. There are no heat and volume fluxes from the coastal boundary.

[11] The hydrodynamic model is coupled with a twodimensional ice model that consists of ice dynamics and ice thermodynamics. The ice dynamic model employs the elastic-viscous-plastic rheology of Hunke and Duckowicz [1997], with one category of ice thickness for each cell. Redistribution of the ice area and thickness is calculated in 


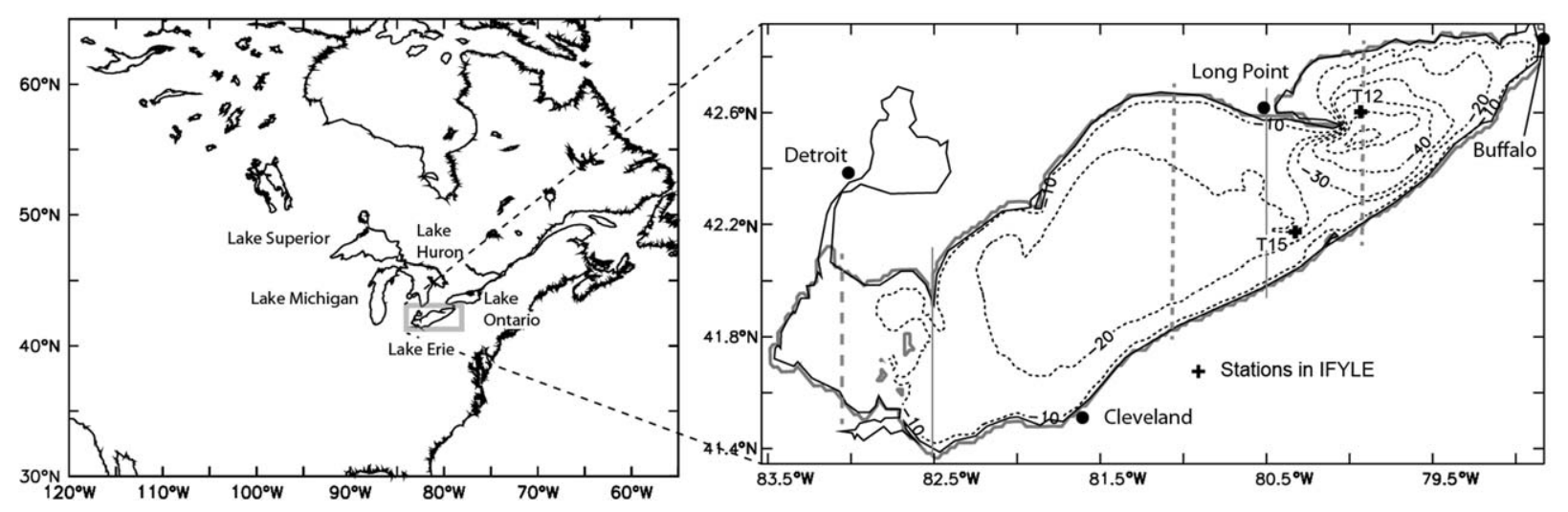

Figure 1. (left) Geographical location of the Great Lakes that includes Lake Erie shown as a rectangular region. (right) Computational domain covering all of Lake Erie, shown by the thick gray line. Note that Lake St. Clair is not included. Dashed thin lines are isobaths with contour intervals of $10 \mathrm{~m}$. Thick dashed lines are at $83.05^{\circ} \mathrm{W}, 81.11^{\circ} \mathrm{W}$, and $79.9^{\circ} \mathrm{W}$, respectively, along which the vertical sections of water temperature are shown in Figure 10 . Thin solid lines at $82.5^{\circ} \mathrm{W}$ and $80.5^{\circ} \mathrm{W}$ are boundaries that define the western, central, and eastern basins.

a semi-Lagrangian scheme: A subgrid ice area in a rectangular shape is defined in each cell as well as velocities on the four sides. After one advection step, a new subgrid ice area is calculated so that ice volume and momentum are conserved. The air-water drag coefficient is calculated as a function of stratification of the atmospheric boundary layer [Liu and Schwab, 1987; Schwab and Bedford, 1999; Wang et al., 2010b]. Following Wang et al. [2010b] and Fujisaki et al. [2012], the air-ice drag coefficient is assumed to be a constant $2.3 \times 10^{-3}$ (a value for smooth young ice given in Wadhams [2002]), which is mostly larger than the air-water drag coefficient for wind speed of $0-20 \mathrm{~m} / \mathrm{s}$ under unstable stratification of the atmospheric boundary layer. The ice thermodynamic model is similar to Parkinson and Washington [1979] with the zero-layer ice thermodynamics [Semtner, 1976], except that snow cover is not taken into account in our model. The exclusion of snow cover may result in less ice growth in the model, as snow cover generally has higher albedo and reduces the absorption of shortwave radiation. The ice surface albedo is a constant of 0.7 , but is reduced to 0.5 when surface melting occurs in order to express the reduced albedo of melted water on the ice surface.

[12] Distributed-memory parallelization is employed for the model using the message-passing interface. Based on the global linear stability criteria proposed by Wang [1996], the minimum depth was set to $3 \mathrm{~m}$ according to the stability condition, $h_{\min }+\zeta_{\max }>0$, where $h_{\min }$ is the minimum water depth, and $\zeta_{\max }$ is the maximum water elevation possibly caused by strong (gust) winds and storm surges along the coast. Based on the Courant-FriedrichsLewy (CFL) criterion, one of the global stability conditions, the time steps for the hydrodynamic model are $20 \mathrm{~s}$ for the external mode (vertically uniform flow) and $150 \mathrm{~s}$ for the internal mode (flow with vertical structure). The time steps for the ice processes are $30 \mathrm{~s}$ for ice dynamics and $150 \mathrm{~s}$ for ice thermodynamics. The initial condition of the lake is at rest with a uniform water temperature of $0{ }^{\circ} \mathrm{C}$. The model was run from 1 April 2003 to 17 April 2012 (nine winters). For hydrodynamics and the water surface temperature, results after 18 April 2003 are utilized for the analysis. The short spin-up time can be accepted because of the shallowness of the lake, as is the case in Lake Michigan [Beletsky and Schwab, 2001]: External gravity waves cross the lake in 0.3 days. In terms of thermodynamics, the water column is completely mixed by overturn in spring and fall that resets the lake's thermal structure. This also allows us to avoid multiyear spin up. In a test case, where the model was run for April 2003 to March 2004 repeatedly, we confirmed that the results after 10 days were almost identical to those after a 3 year spin up. For three-dimensional thermodynamics, we use results after 1 May 2003, that is, after the first spring overturn.

\subsection{Data}

[13] Hourly atmospheric forcing applied to the model are wind speed at $10 \mathrm{~m}$ height, surface air temperature, dew point, and cloud fraction. They are based on surface meteorological measurements around Lake Erie. The 29 stations used include those from the National Data Buoy Center and the Coastal Marine Automated Network [Wang et al., 2010b]. The station data are interpolated into the model grid based on an objective analysis [Schwab and Bedford, 1999], with an update of a spatial interpolation technique (the "natural neighbor" interpolation [Beletsky et al., 2003]).

[14] The Great Lakes Surface Environmental Analysis (GLSEA) of surface water temperature is utilized to evaluate the model results. The data is produced by the National Oceanic and Atmospheric Administration/Great Lakes Environmental Research Laboratory (GLERL)/CoastWatch Program. The lake surface temperature is based on the Advanced Very High Resolution Radiometer (AVHRR) imagery. Note that lake surface temperature below the ice cover is approximated by the freezing temperature, i.e., $0^{\circ} \mathrm{C}$. Ice concentration is taken from the GLERL ice atlas (http://www.glerl.noaa.gov/data/ice/atlas/) [Wang et al., 2012b], which is based on Radarsat-2, Envisat, AVHRR, Geostationary Operational and Environmental Satellites (GOES), and Moderate Resolution Imaging 
Spectroradiometer (MODIS). The spatial resolution for the ice analysis is $2.55 \mathrm{~km}$ until 2006, and $1.8 \mathrm{~km}$ afterward. Ice thickness field observations were conducted on Lake Erie by GLERL with U.S. Coast Guard helicopter support on 27 February 2008 (9 sites), 26 February 2009 (20 sites), and 3 March 2010 (20 sites). The measured ice thicknesses are used to compare with the modeled ice thicknesses.

[15] For discussion of low and high ice coverage's linkage with teleconnection patterns, we use the sea level pressure field from the National Centers for Environmental Prediction/National Center for Atmospheric Research reanalysis data set, and the monthly NAO index from NOAA's Climate Prediction Center.

\section{Model Results}

\subsection{Ice Extent, Ice Production, and Ice Thickness}

[16] The simulation period covers two severe winters, 2009 and 2011, and two mild winters, 2006 and 2012. Here we define winter of a particular year as a period from December in the previous year to April. In the mild winter of 2006, the winter air temperature averaged from January to March was $1.1^{\circ} \mathrm{C}$, which was $0.7^{\circ} \mathrm{C}$ above the 9 year mean. In the severe winters of 2009 and 2011, the winter air temperatures were $-0.5^{\circ} \mathrm{C}$ and $-0.6^{\circ} \mathrm{C}$, which were $0.9^{\circ} \mathrm{C}$ and $1^{\circ} \mathrm{C}$ below the 9 year means, respectively. The winter of 2011-2012 was one of the warmest over the contiguous United States, including the Great Lakes region. The air temperature in March was the highest on record, dating back to 1895 . The winter air temperature over Lake Erie was $3.1^{\circ} \mathrm{C}$, which was $2.7^{\circ} \mathrm{C}$ higher than the 9 year mean.

[17] Monthly breakdown of ice production, air temperature, and the three-dimensional water temperature are shown in Figure 2. Most of the ice production in Lake Erie occurred in January and February, during which the air temperature was below or close to the freezing temperature $\left(0^{\circ} \mathrm{C}\right)$. The mean water temperature lowered to the minima $\left(0.1-1.9^{\circ} \mathrm{C}\right)$ in February. In some winters, significant production of ice occurred in March $(2005,2007,2009$, and 2011). In the winter of 2007 , ice production in January was unusually small due to the anomalously warm air temperature in that month. The corresponding mean water temperature in January was anomalously warm. In the mild winters of 2006 and 2012, the minimum mean water temperature was $1.2^{\circ} \mathrm{C}$ and $1.9^{\circ} \mathrm{C}$, which is $0.7^{\circ} \mathrm{C}$ and $1.4^{\circ} \mathrm{C}$ above the 9 year mean, respectively. In the mild winter of 2012 , very little ice production occurred in January and February.

[18] The anomalously severe and warm winters are reflected in the cumulative freezing degree days in Figure 3. The cumulative freezing degree days are calculated as $\int_{\text {December }}^{\text {April }} \Delta T \Delta t$, where $\Delta T$ is the temperature difference from the freezing temperature (i.e., $0^{\circ} \mathrm{C}$ ). When the air temperature is above the freezing temperature, $\Delta T$ is zero. A significant amount of cumulative freezing degree days was also found in the winter of 2007, due to the contribution of strong cold air in February 2007 (Figure 2b). However, the contrasting warm January in that year resulted in a seasonal mean air temperature close to the 9 year mean. Hence, we do not include the winter of 2007 in the defined characteris-
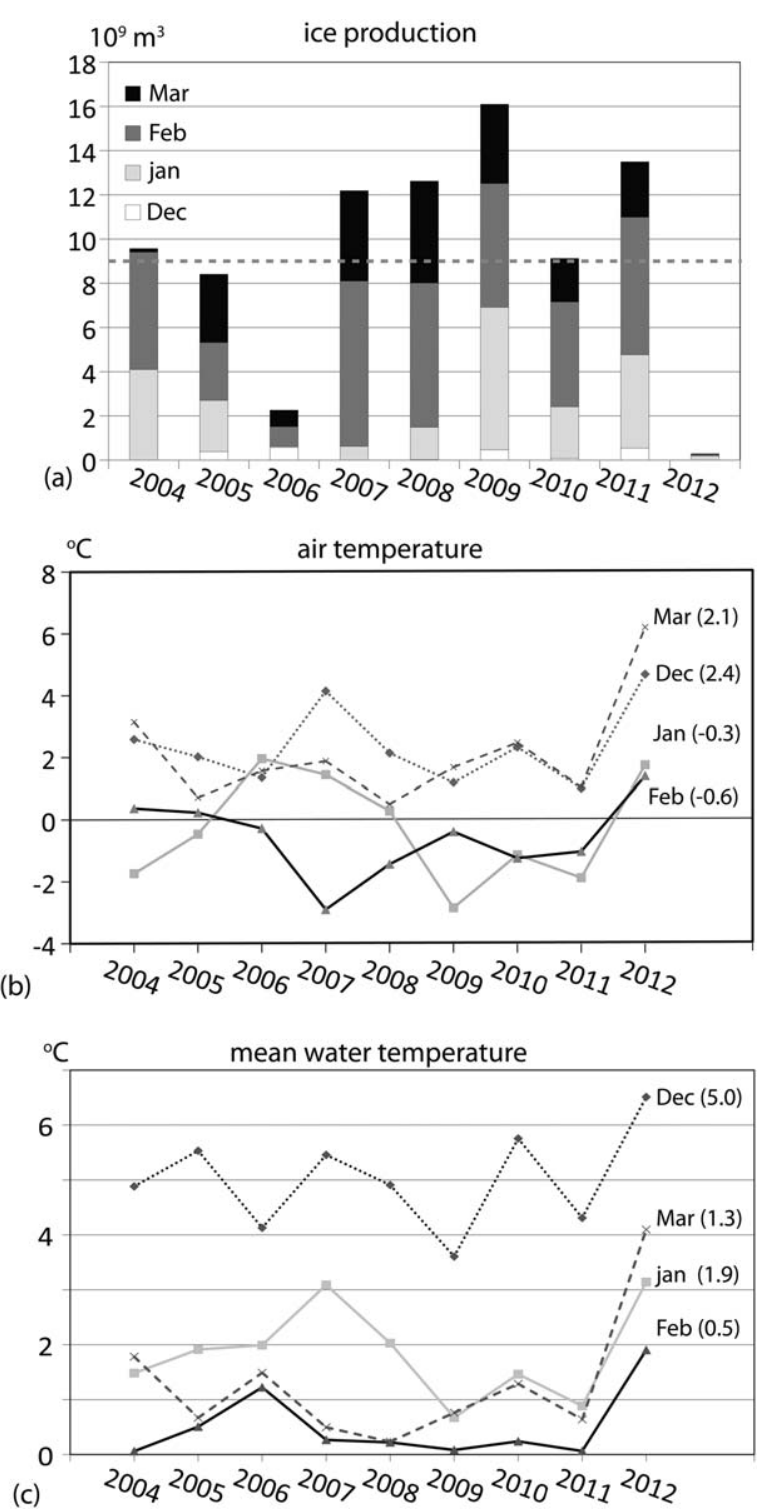

Figure 2. Monthly values from December to March. (a) Volumetric production of ice, (b) air temperature, and (c) three-dimensional mean water temperature. Digits in parentheses of Figures 2b and 2c are mean through 2004-2012.

tic severe winters. As seen in the polar oceans, cumulative freezing degree days are generally correlated with volumetric productions of ice [Wadhams, 2002]. The correlation between the two variables is significantly high with a correlation coefficient of 0.95 . The characteristic severe (mild) winters resulted in anomalously large (small) ice production in the model results. The correlation appears to be slightly weaker prior to the winter of 2009 (Figure 3b). This is likely related to anomalous initial water temperatures that are represented in the mean water temperature in December (Figure 2c). From the winter of 2009 and onward, the mean water temperatures in December had similar year-to-year changes to the cumulative freezing degree days multiplied by -1 , while they were out of phase prior to the winter of 2009 , likely responsible for the slightly weaker correlation. 


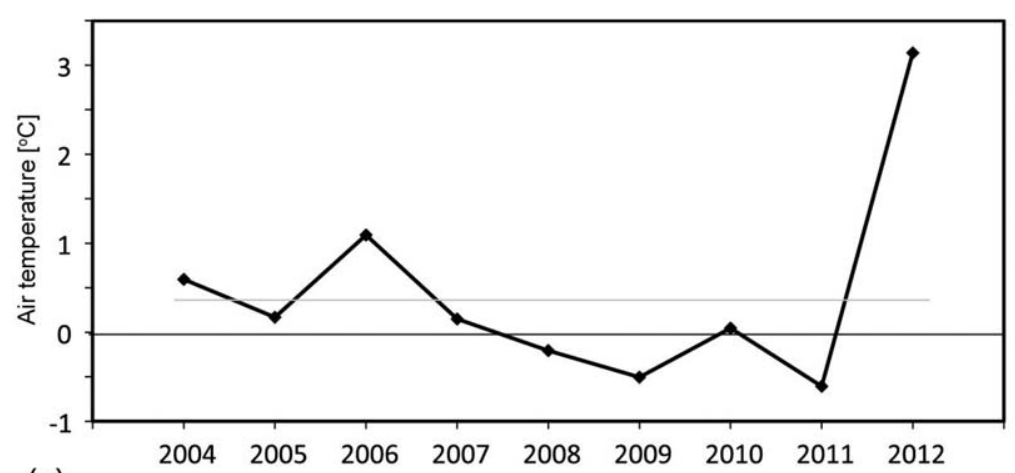

(a)

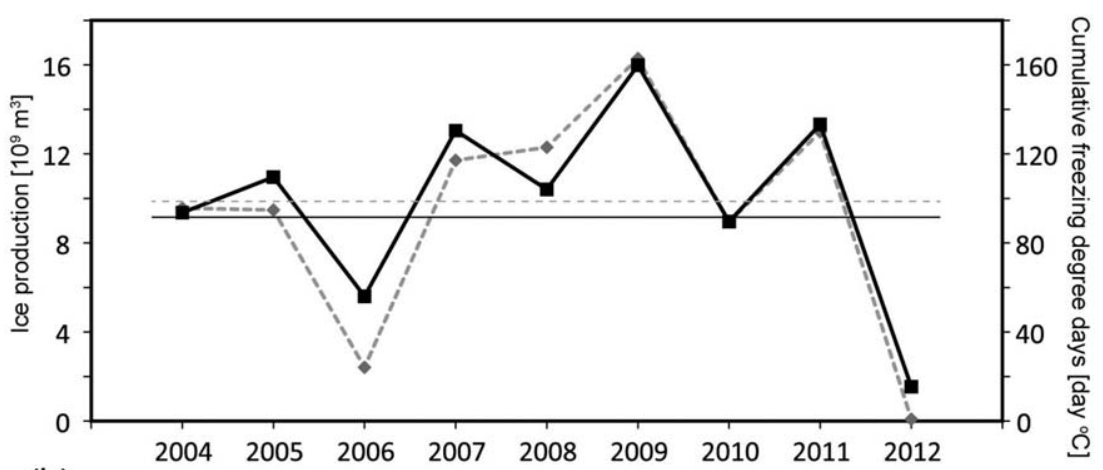

(b)

Figure 3. (a) Winter mean air temperature, from January to March. The 9 year mean of $0.43^{\circ} \mathrm{C}$ is also shown with a gray line. (b) Cumulative freezing degree days (black solid) and ice production (gray dashed). The 9 year means of 99.1 day ${ }^{\circ} \mathrm{C}$ (black) and $9.2 \times 10^{9} \mathrm{~m}^{2}$ (gray) are also shown. The correlation coefficient between the ice production and the cumulative freezing degree days is 0.95 .

[19] Figure 4a shows the simulated time series of ice area from December 2003 to April 2012 (9 winters). Maximum and annual ice areas are shown with root-mean-square errors (RMSEs) in Table 1. The interannual variation of annual ice area is reasonably simulated by the model in comparison with the ice analysis. The high annual ice cover in the winters of 2007, 2008, 2009, and 2011 correspond to the simulated large annual productions of ice. The model somewhat underestimated the annual ice area in 2005 with the highest RMSE of $7 \times 10^{3} \mathrm{~km}^{2}$. The lowest annual ice extents in the winter of 2006 and 2012 are consistent with the simulated lowest ice productions in the two seasons. The 9 year means and the standard deviations are shown in Figures $4 \mathrm{~b}$ and $4 \mathrm{c}$. The standard deviation is large, being close to the 9 year annual mean values. This is consistent with the observational finding by Wang et al. [2012a, 2012b] that the standard deviations (i.e., variability) of ice cover in the Great Lakes are larger than the climatological means for each lake.

[20] Figure 5 shows examples of maximum ice extent in the mild winters of 2006 and 2012, and in the severe winters of 2009 and 2011. Large fractions of open water remained at the peak extent in the mild winters, when the lake is entirely ice covered in normal years. In the winter of 2012, lake ice only existed in a small fraction of the western basin even at the maximum extent. On the other hand, the lake was characterized by high ice coverage in the severe winters of 2009 and 2011.

[21] It is likely that the model has less performance in reproducing fractional ice cover. In 2006 and 2009, the observed maps show large areas with partial ice cover $(50-$ $70 \%$ ) along the northern coast in the central basin, which are not simulated by the model. The modeled maps have only very narrow zones of partial ice cover between the areas of complete ice cover and none at all. There is also an inconsistency near Long Point in 2011; the model simulated a small open water region that was not observed. While the mode shows tolerable performance in reproducing lake-wide ice area (Figure 4a), the model needs further improvements to reproduce the detailed ice distribution in

Table 1. Maximum and Annual Ice Areas Over Lake Erie From the Winter of 2004-2012 a

\begin{tabular}{lccc}
\hline & Model & Observational Analysis & RMSE \\
\hline 2004 & $25.6(8.4)$ & $25.7(10.3)$ & 4.2 \\
2005 & $17.5(6.2)$ & $23.9(11.6)$ & 7.0 \\
2006 & $9.9(1.5)$ & $6.3(1.2)$ & 1.3 \\
2007 & $25.6(9.7)$ & $24.3(9.9)$ & 4.3 \\
2008 & $25.6(10.3)$ & $22.9(10.1)$ & 3.4 \\
2009 & $25.6(13.6)$ & $23.4(11.7)$ & 4.6 \\
2010 & $23.5(8.1)$ & $23.0(8.3)$ & 4.3 \\
2011 & $25.5(12.9)$ & $23.8(12.7)$ & 4.5 \\
2012 & $2.4(0.2)$ & $3.5(0.3)$ & 0.4 \\
\hline
\end{tabular}

${ }^{\mathrm{a}}$ Annual ice areas that are shown in parentheses are calculated by averaging ice areas through mid-December in the previous year to mid-April. Values from the observational analysis based on the National Ice Center Great Lakes Ice Analysis Charts and the root-mean-square errors (RMSE) are also shown. Units are all in $10^{3} \mathrm{~km}^{2}$. 


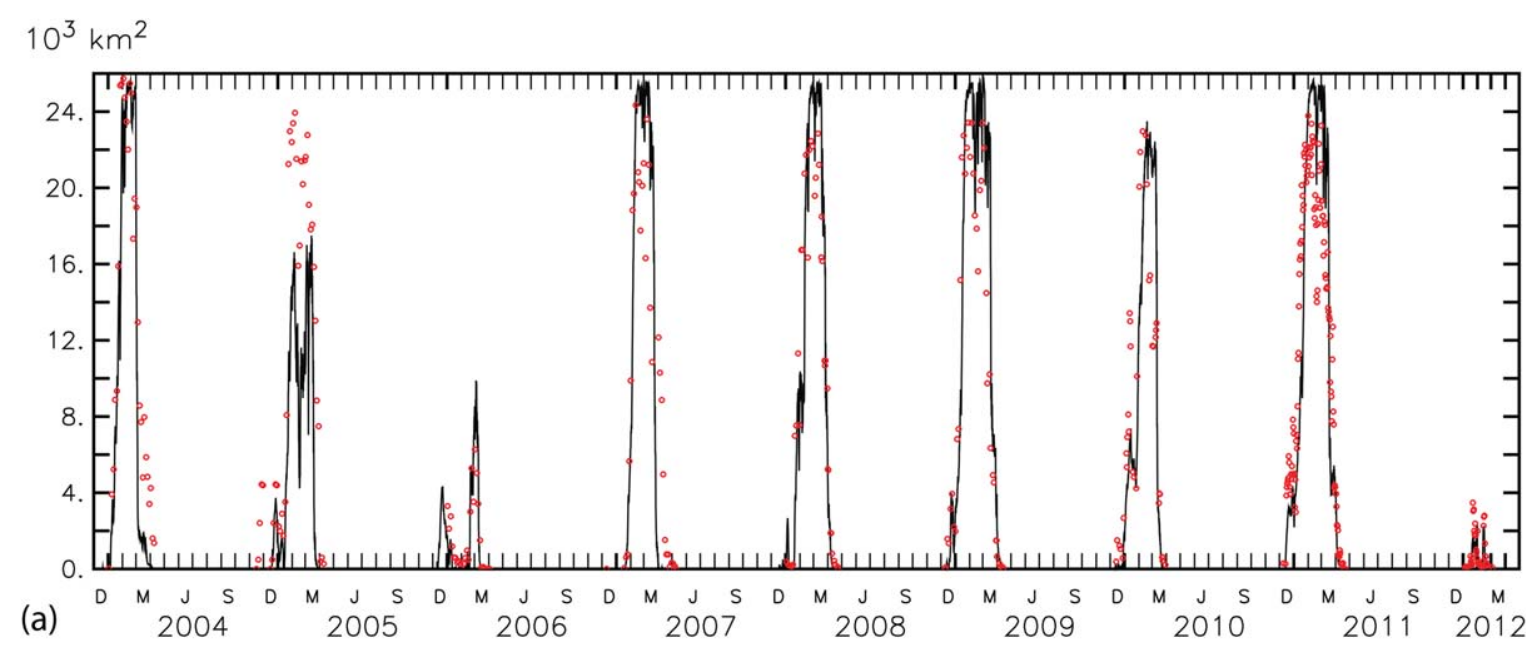

(b)
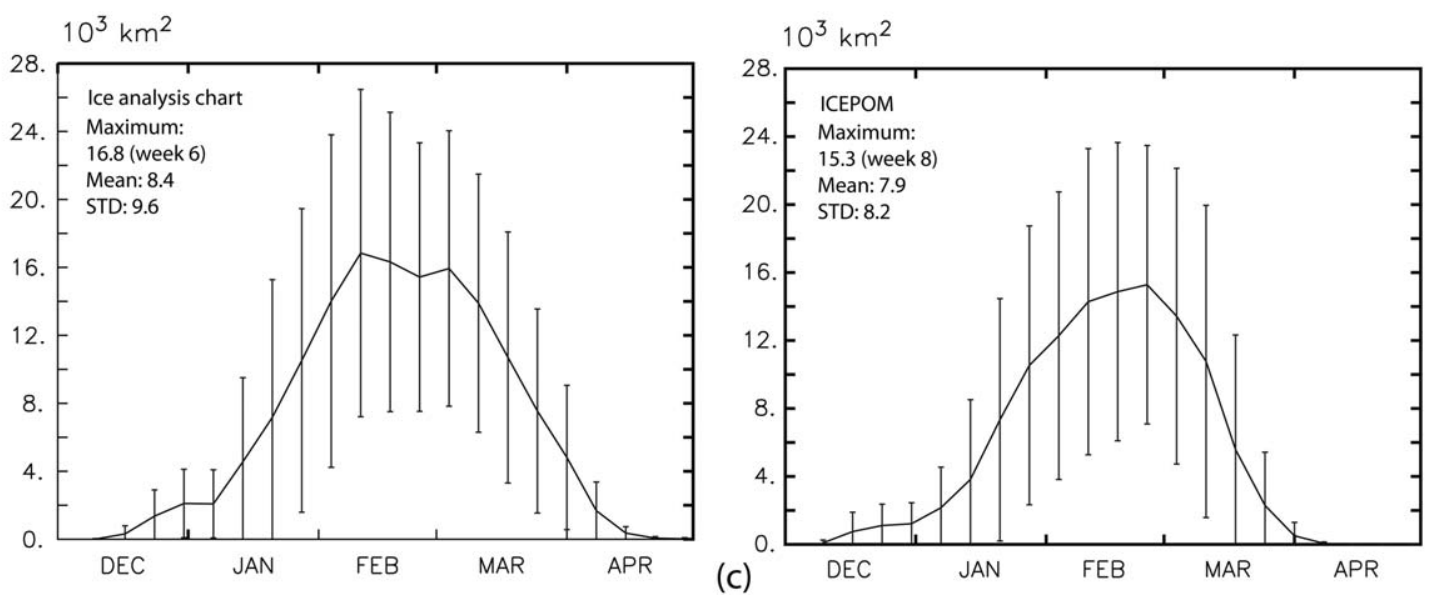

Figure 4. (a) Time series of total ice area from December 2003 to April 2012. Thick lines are from the model result, and red symbols are from the observational analyses based on the National Ice Center Great Lakes Ice Analysis Chart. The observational analyses are biweekly until the winter of 2009-2010, and daily afterward. (b) Weekly 9 year means are also shown for the ice analysis chart and (c) the model results. Bars in Figures $4 \mathrm{~b}$ and $4 \mathrm{c}$ denote the standard deviation.

the lake. A more detailed spatial representation of the meteorological forcing could improve this point.

[22] Figure 6 shows ice thickness fields from the model and the field observations. It should be noted that the modeled ice thicknesses are cell averaged over a $2 \mathrm{~km} \times 2 \mathrm{~km}$ area, and therefore are somewhat different from the observed point values. However, here it is assumed that the observed point values could roughly represent spatial means over the computational cells. During the measurements in the 3 years, the lake was mostly ice covered, and the observed ice thicknesses ranged from 0 to $50 \mathrm{~cm}$. Relatively thick ice was observed along the southern coasts of the eastern and central basins, which is likely due to the mean southwesterly wind during winter that advected and piled up ice along the coasts. The model also simulates these trends (Figure 6, right), but shows some larger values with a few outliers of more than $1 \mathrm{~m}$ (e.g., $107 \mathrm{~cm}$ at $79^{\circ} \mathrm{W}, 42.8^{\circ} \mathrm{N}$ in 26 February 2009 ). In the western basin, both the model and the observations showed relatively small ice thickness in all 3 years. Figure 7 shows a scatter plot of the modeled and the observed ice thicknesses. While a relatively large number of values are within a devi- ation of $\pm 10 \mathrm{~cm}$, some values are significantly under-or overestimated. There are four outliers that were overestimated by the model, exceeding a $+25 \mathrm{~cm}$ deviation. These outliers commonly occurred in the eastern basin, where there was extensive wind-driven mechanical convergence of ice. The model used a simple ice mechanical deformation model [Hibler, 1979], where mean ice thickness mechanically increases by convergence of ice into a cell to conserve a volume of ice. The model does not include a mechanical decrease of mean ice thickness, for example, by turning over of large ice floes. This exclusion might overestimate ice thickness, while some alternative mechanical deformation models [e.g., Thorndike et al., 1975] might improve the performance. This point needs to be improved in the future modeling work.

\subsection{Seasonal Thermal Structure}

[23] Figure 8 shows the seasonal variation of lake-wide averaged lake surface temperature based on the 9 year mean through 2003-2012. The model simulates the lakewide averaged lake surface temperature with only a small deviation from the GLSEA data. The root-mean-square 

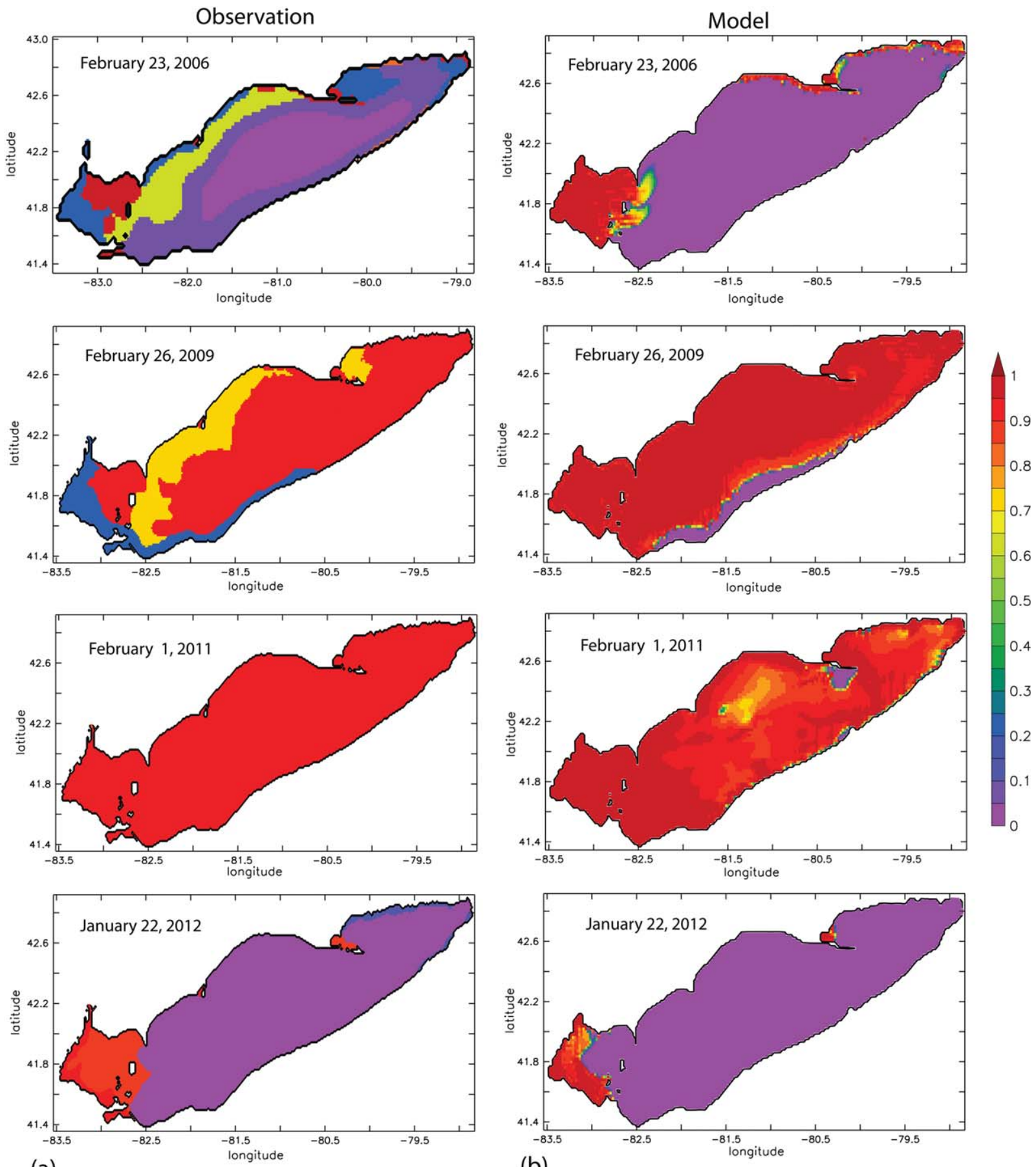

(a)

(b)

Figure 5. Maximum ice coverage in the severe and mild winters. 23 February 2006 (mild), 26 February 2009 (severe), 1 February 2011 (severe), and 22 January 2012 (mild). Right plots are from the model results, and left plots are from the ice analysis gridded data at National Ice Center. The spatial resolutions for the ice analysis used are $2.55 \mathrm{~km}$ for 2006, and $1.8 \mathrm{~km}$ for 2009, 2011, and 2012.

error is $0.6^{\circ} \mathrm{C}$. The lake surface temperature has a large seasonality, with a high of $24^{\circ} \mathrm{C}$ in July to August, and a low close to the freezing temperature in February. The monthly standard deviations ranged from $0.5^{\circ} \mathrm{C}$ to $1.2^{\circ} \mathrm{C}$ for the model and from $0.6^{\circ} \mathrm{C}$ to $1.4^{\circ} \mathrm{C}$ for GLSEA. Interannual variation represented by the monthly standard deviations is relatively large in March $\left(1.2^{\circ} \mathrm{C}\right.$ for the model and $1.3^{\circ} \mathrm{C}$ for GLSEA), likely due to the influence of the strong inter- annual variability of ice cover, whose areal fraction greatly changes the incident solar radiation. In April, the spring overturn may explain the relatively small interannual variation. May to July also showed large interannual variation (larger than $1{ }^{\circ} \mathrm{C}$ and $1.3^{\circ} \mathrm{C}$ for the model and GLSEA, respectively), likely due to the onset of strong near-surface stratification in summer that made the surface heat capacity low and water temperature sensitive to the interannual 

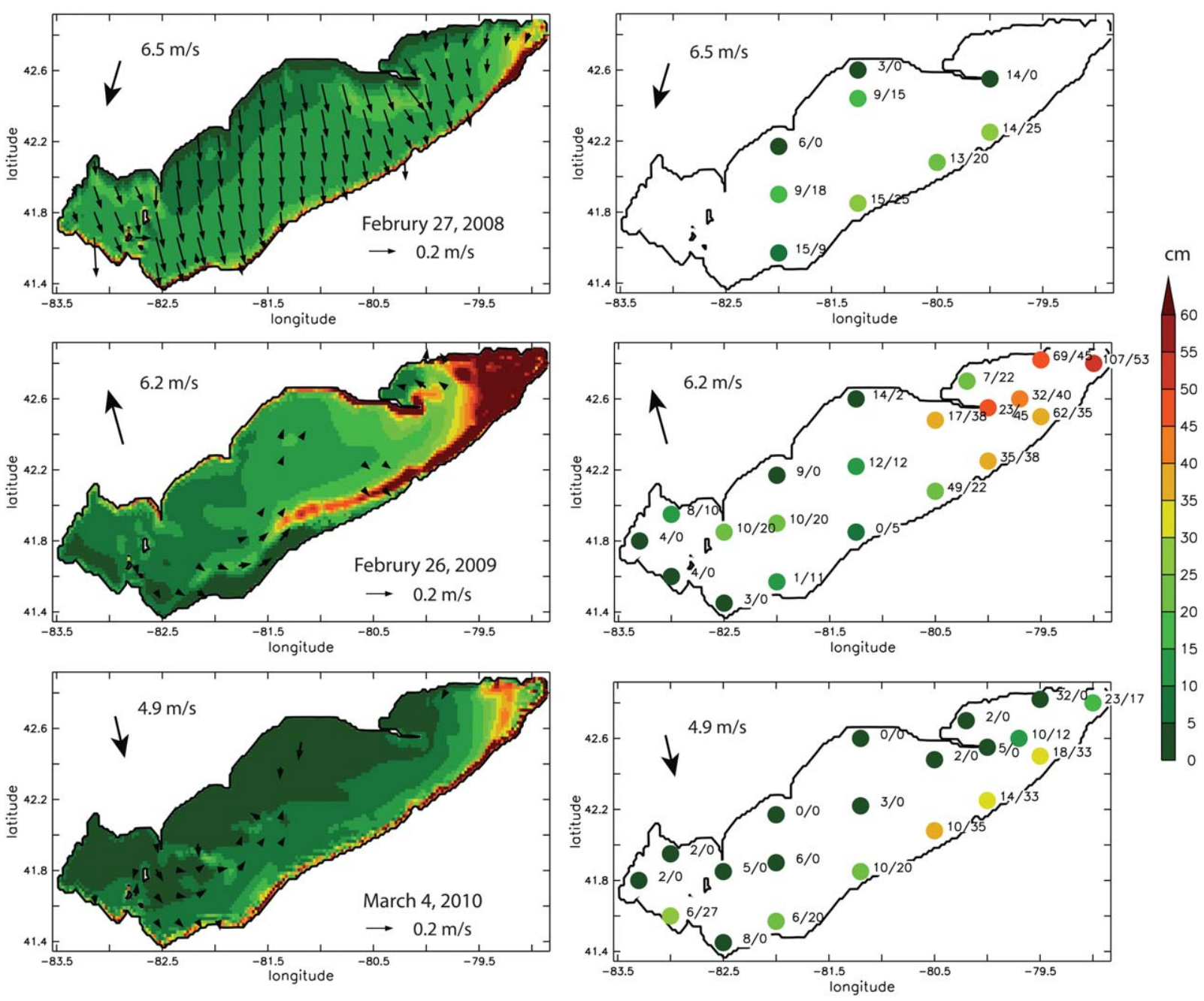

Figure 6. Ice thickness fields (centimeter) on (top) 27 February 2008, (middle) 26 February 2009, and (bottom) 4 March 2010. Left plots are from the model results, and right plots are from the field observations conducted by GLERL with the U. S. Coast Guard helicopter support. Numbers next to circles in the right plots are the modeled/observed ice thickness (centimeter) at the measurement sites. Vectors on the modeled ice thickness fields are ice velocities, whose magnitude smaller than $0.05 \mathrm{~m} / \mathrm{s}$ are not shown. Vectors in the left plots outside of the lake are daily means of wind $|\mathrm{V}| \mathrm{V} / \overline{\mathrm{V}}$, where $\mathrm{V}=\left(U_{a,}, V_{a}\right)$ denotes the lake-wide mean wind, and a bar denotes daily averaging. Digits with arrows denote the mean wind speed $\overline{\mathrm{V}}$.

variation of air temperature. In fall and winter, the mean surface water temperature showed relatively small interannual variation, except for October, to which the unusually warm air temperature in October $2007\left(3.1^{\circ} \mathrm{C}\right.$ above the 9 year mean) likely contributed.

[24] During the International Field Years on Lake Erie program (IFYLE), the mooring thermistor measurements were conducted by National Water Research Institute, Environmental Canada (NWRI) and GLERL. The depths of mooring thermistors were from near surface to near bottom. In comparison with the thermistor measurements at two IFLYE sites in 2004, the model reproduced the seasonal variation of thermal structure in 2004 reasonably (Figure 9). As the parameterization for the bottom roughness length was updated from Fujisaki et al. [2012], the mixing near the bottom was reduced, resulting in better agreement with the observations. The 9 year means of summer thermal structure in summer are characterized by stratification (Figure 10). In the eastern basin (deepest), the strong vertical gradient of temperature is found with the warm surface temperature of about $23^{\circ} \mathrm{C}$ and the cold hypolimnion of about $6^{\circ} \mathrm{C}$ in the deepest basin as a remnant of winter cooling. The western basin shows relatively uniform water temperature in the vertical direction, because summer warming easily reaches the bottom due to the lake's shallow depth. The isotherm in the western basin is domed due to faster warming near the shallower coastal region. On the other hand, in the central basin, the modeled thermocline is bowl shaped. The observed transection of water temperature in the central basin in the summer of 2005 was characterized by a bowl-shaped thermocline [Beletsky et al., 2012]; so is the modeled 9 year mean thermal structure in summer (Figure 10). Figure 11a shows the modeled vertical profile of water temperature along a 


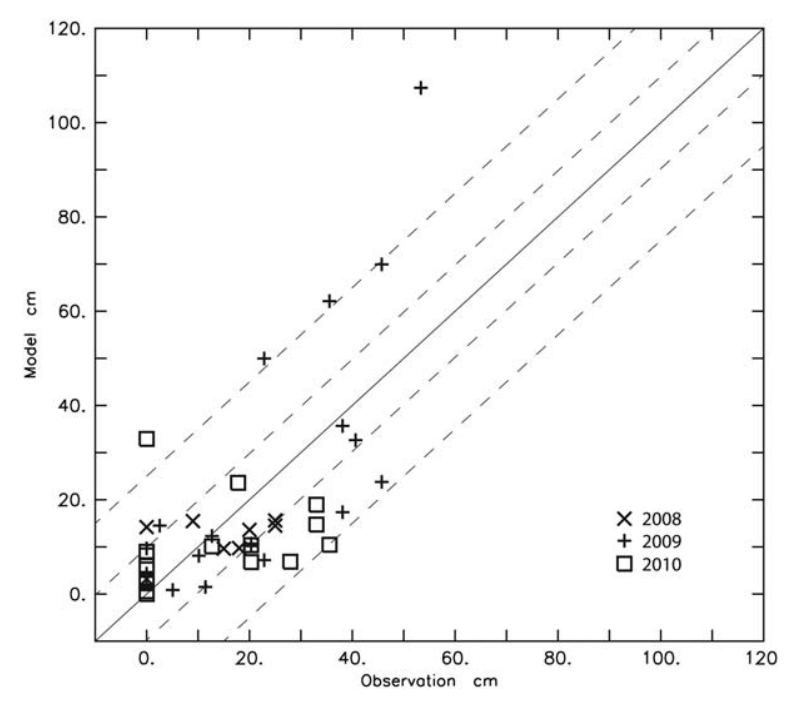

Figure 7. Scatter plot of ice thickness. Modeled and observed values in the winters of 2008, 2009, and 2010. The measurement sites and dates are shown in Figure 6. Corresponding modeled ice thickness is taken from a cell that is closest to each measurement site. Lines of $y=x$ (solid) and $y=x \pm 10, \pm 25 \mathrm{~cm}$ (dashed) are also shown.

Plankton Survey System transect [Beletsky et al., 2012] on 9 July 2005. The nearshore-offshore temperature gradient was reasonably reproduced in comparison with the observation (Figure 11b), while the modeled thermocline is somewhat shallow compared with the observation. Beletsky et al. [2012] related the bowl-shaped thermocline in the central basin to the negative wind stress curl over the region in summer, in association with Ekman downwelling. The modeled wind stress curl was also characterized by negative vorticity in the central basin in the summer of 2005 (Figure 11c), while it was somehow confined to the northern part.

[25] While a thin mixed layer is found near the surface in summer, water temperature becomes vertically uniform in late fall in the three basins (Figure 12), as the atmospheric cooling and the wind mixing cause the fall overturn. This is characteristic for Lake Erie, which is shallow, so winter cooling and wind can mix throughout the water column (Figure 12). An exception is in the deepest region of the eastern basin, where a relatively warm hypolimnion exists (Figure 10). The layer of warm hypolimnion decreases as the lake cools down, but a small amount of the relatively warm layer $\left(\sim 1^{\circ} \mathrm{C}\right)$ remains during the cold peak in March (Figure 14, discussed later). However, this hypolimnion collapses eventually due to the spring overturn. From late March to April, surface warming causes the spring overturn when the freshwater reaches its maximum density at $4^{\circ} \mathrm{C}$, followed by the formation of a thin mixed layer near the surface due to stratification. The mixed layer depth becomes smallest around mid June. The simulated minimum depth is $4 \mathrm{~m}$, which is similar to the observed values of $5 \mathrm{~m}$ by Schertzer et al. [1987]. The simulated thermocline in summer was diffuse in comparison with in situ observations. The excessive diffusion was also identified in the previous studies that used a similar hydrodynamic model for the Great Lakes [Beletsky and Schwab,
2001; Dupont et al., 2012; Fujisaki et al., 2012]. We also tested a case in 2004 using the wind-wave mixing model by $H u$ and Wang [2010], as it produced improved thermocline development in southern Lake Michigan [Luo et al., 2012; Bai et al., 2013]. However, it did not change the results in our model, showing negligible difference from the modeled thermocline development (Figure 9).

[26] The interannual variation of the temperature profile anomaly (Figure 13) shows a relatively weak variation during winter due to near freezing temperatures for the whole water column, except for a significant positive anomaly in the winter of 2012. In contrast, the summer thermal structure shows a large interannual variation. The temperature anomalies that originate below the mixed layer propagate downward with time, as the anomaly in the lower layer is gradually cooled by wind mixing, and the history of the anomaly disappears mostly by December (fall overturn).

[27] The thermal structure in the record warmest month, March 2012, showed a characteristic pattern (Figure 14). In addition to the anomalously warm water temperature in the three sections, it is notable that the water is significantly stratified compared with the 9 year mean. Note that the thermal structure of the other warm March, in 2006, was similar to the 9 year mean, but with a positive anomaly. Based on the 9 year climatology, early spring warming causes vertical convection in the Great Lakes, as the fresh water reaches its maximum density at $4^{\circ} \mathrm{C}$, resulting in a vertically homogeneous temperature. The late spring stratification starts in April. However, in March 2012, the unusually warm air temperature caused a much earlier stratification (Figure 14). This early onset of stratification is also seen in the mixed-layer depth in March of 2012 (Figure 13). Obviously, such early stratification accelerated the further surface warming. In the eastern basin, where the heat capacity is larger due to the larger depth $(\sim 60 \mathrm{~m})$, the water temperature is almost homogeneous in the vertical direction, as this was right before onset of stratification. While the winter of 2012 might be somewhat amplified in natural variability, the long-term shift to an earlier start of stratification was reported in Lake Superior by Desai et al.

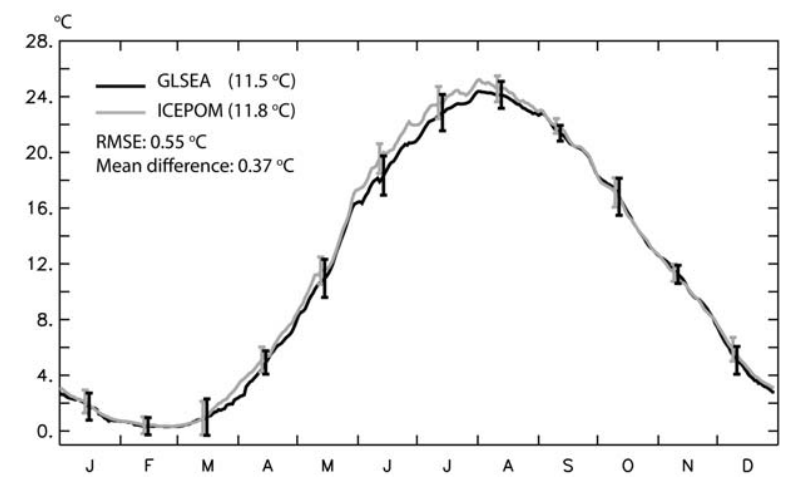

Figure 8. Seasonal variation of lake surface temperature. Daily climatological values are created from 2003 to 2012. Black line is from the Great Lakes Surface Environmental Analysis (GLSEA), and gray line is from the model results. The root-mean-square value and the biases are $0.55^{\circ} \mathrm{C}$ and $0.37^{\circ} \mathrm{C}$, respectively. Bars denote the standard deviations from the 9 year means. 
$\mathrm{T} 15(80.30 \mathrm{~W}, 42.16 \mathrm{~N})$
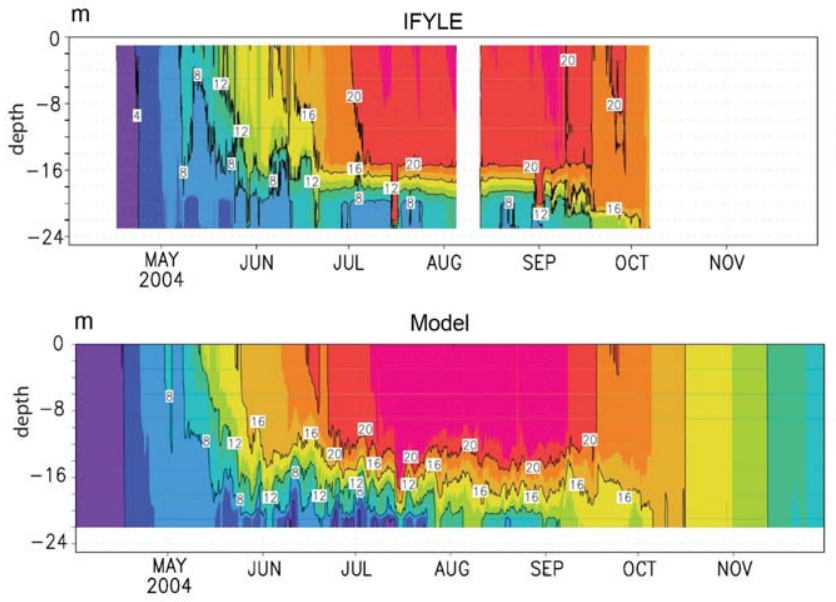

$\mathrm{T} 12(79.93 \mathrm{~W}, 42.58 \mathrm{~N})$
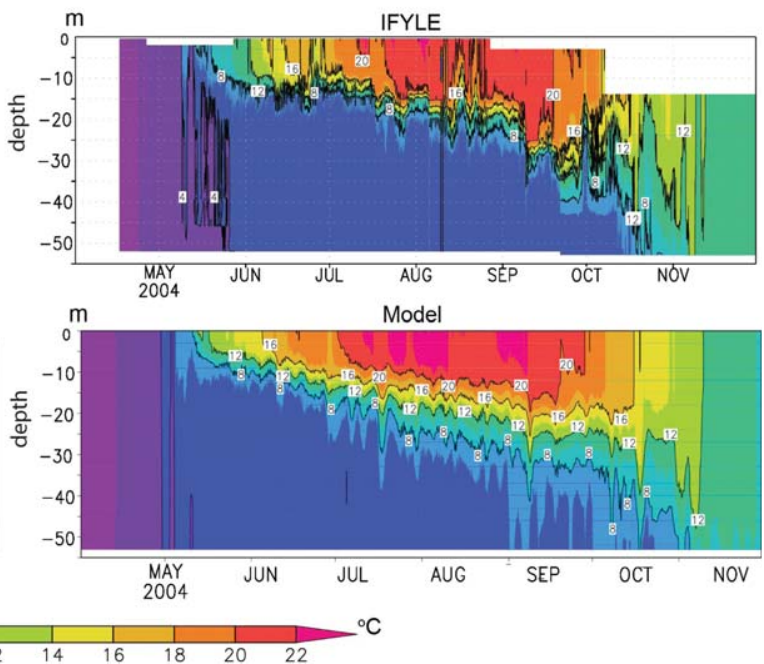

Figure 9. Seasonal evolution of water temperature at two observation sites during the International Field Year on Lake Erie (IFYLE) shown in Figure 1. The observations were based on the thermistor measurements by NWRI and GLERL (only for T15, after day 265 of 2004). The mooring thermistors are at 19 levels from $0.4 \mathrm{~m}$ depth to $52 \mathrm{~m}$ depth for T12 (five levels from $13.9 \mathrm{~m}$ depth to $52.9 \mathrm{~m}$ depth for GLERL thermistor), and 12 levels from $1 \mathrm{~m}$ depth to $23 \mathrm{~m}$ depth for T15.

[2009]. A possible shift to early stratification in Lake Erie would result in faster warming of lake surface temperature and could influence biological activities.

\subsection{Lake Circulation}

[28] Figure 15 shows 3 month mean fields of stream function $\psi=-\int_{y_{s}}^{y_{n}} \bar{u} d y=\int_{x_{w}}^{x_{e}} \bar{v} d y x$ and wind stress curl, which are averaged from 2003 to 2012. $\bar{u}$ and $\bar{v}$ are depthaveraged $u$ and $v$ velocity, respectively. $y_{s}, y_{n}, x_{w}, x_{e}$ are southern, northern, western, and eastern boundaries of the lake, respectively.

[29] Overall, the model reasonably reproduced seasonal circulation patterns. The two-cell pattern in October to December is consistent with the observations in Lake Erie
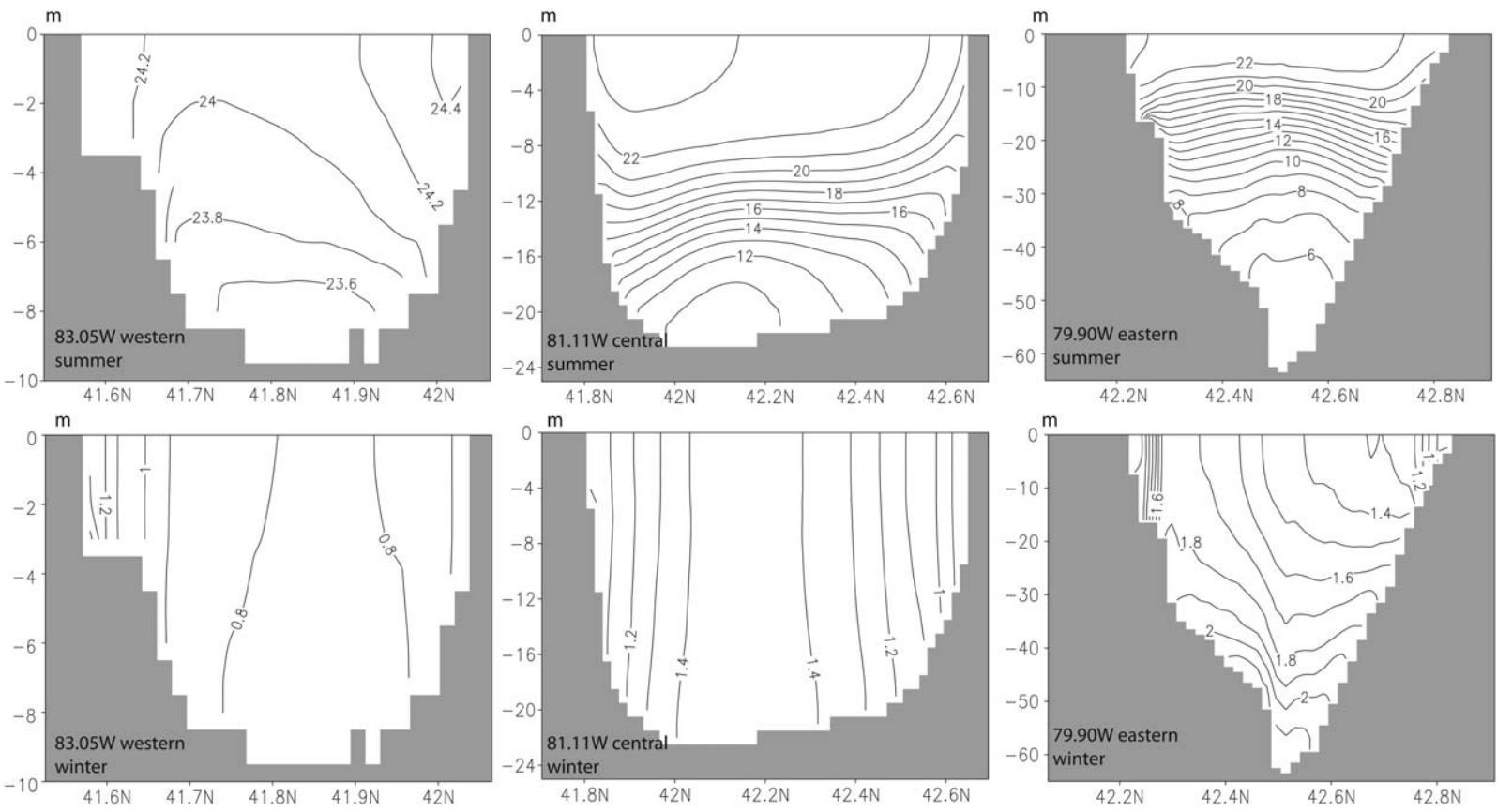

Figure 10. Vertical section of water temperature in the western basin $\left(83.05^{\circ} \mathrm{W}\right)$, the central basin $\left(81.11^{\circ} \mathrm{W}\right)$, and the eastern basin $\left(79.9^{\circ} \mathrm{W}\right)$. (top) July to September (2003-2011 mean) and (bottom) January to March (2004-2012 mean). Contour intervals are $1{ }^{\circ} \mathrm{C}$ for July to September $\left(0.2^{\circ} \mathrm{C}\right.$ for the western basin) and $0.1^{\circ} \mathrm{C}$ for January to March. The model results are vertically interpolated to a $z$ coordinate with $1 \mathrm{~m}$ grids. 
(a)
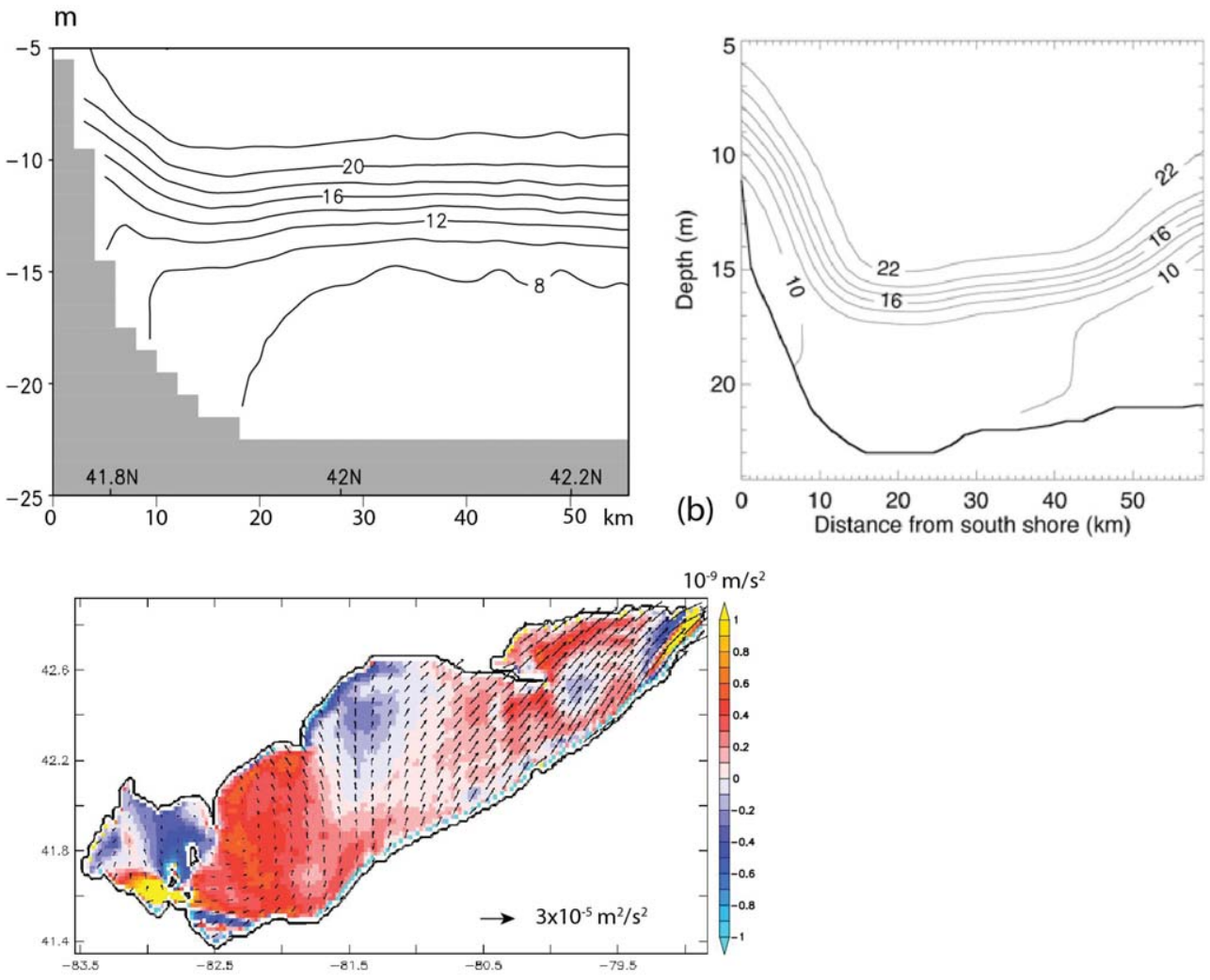

(c)

Figure 11. (a) Vertical section of water temperature $\left[{ }^{\circ} \mathrm{C}\right]$ in the central basin on 9 July 2005. The model results along $81.25^{\circ} \mathrm{W}$. The horizontal range corresponds to a Plankton Survey System transect in Beletsky et al. [2012]. (b) Observation along a Plankton Survey System transect [Beletskly et al., 2012, Figure 1b] on 9 July 2005. (c) Wind stress curl and wind stress vector in the summer of 2005 (July to September mean).

(Figure 6 "winter" in Beletsky et al. [1999]). This is consistent with the modeled stream function in Lake Erie [Saylor and Miller, 1987], where the uniform southwesterly wind was applied to the homogenous lake. Bennett's [1974] vertical cross section models for Lake Ontario predicted the direction of the vertically averaged alongshore current was in the same direction as the wind in shallow water and opposite the wind direction in the deep water, regardless of stratification. However, stratification caused the alongshore current (coastal jet) to be wider and more surface confined. Similar physics can be applied to Lake Erie, as the lake has a similar southwest-northeast orientation and is under the same synoptic wind. In the eastern basin, an independent two-cell pattern is identified, likely due to its isolated topography from the central basin.

[30] The three gyre patterns appeared in summer, consisting of the anticlockwise gyres in the western part of central basin and eastern basins, and a clockwise gyre in the central basin (July to September in Figure 15). They are consistent with the previous observational and theoretical studies [Saylor and Miller, 1987; Beletsky et al., 1999, 2012; Schwab et al., 2009; Leon et al., 2005]. The clockwise gyre in the central basin may be somewhat small compared with the schematic features based on the observations [Saylor and Miller, 1987; Beletsky et al., 2012]. As is mentioned in section 3.2, Beletsky et al. [2012] attributed the clockwise gyre formation in the central basin of Lake Erie in summer to the negative wind stress curl over the region. The clockwise gyre in our model results could correspond to the relatively small region of negative wind stress curl (Figure 15). However, the detailed comparison of the modeled circulation with their observations may be difficult due to the relatively sparse observations and different temporal coverage. In summer, winds may not be the only factor that dominantly determines the lake circulation. Schwab and Beletsky [2003] showed that the effects of baroclinicity during the stratified period were important in Lake Michigan. They also showed that cyclonic wind stress vorticity generated by atmospheric stability gradients [Emery and Csanady, 1973] could be significant. Both mechanisms are favorable for a cyclonic circulation in a stratified period. Further pursuing the relative importance of negative wind stress curl, barocinicity, and the topography in summer Lake Erie would be worthy, but as our focus in this paper is on winter dynamics, we will leave it to future work.

[31] In January to March, the simulated circulation is cyclonic over the western and the central basin, being consistent with the positive wind stress curl over the region. In the western basin, the flow is very weak. In the eastern basin, a two-cell circulation is observed. In April to June, the circulation is entirely cyclonic due to the positive wind stress curl over the lake. 

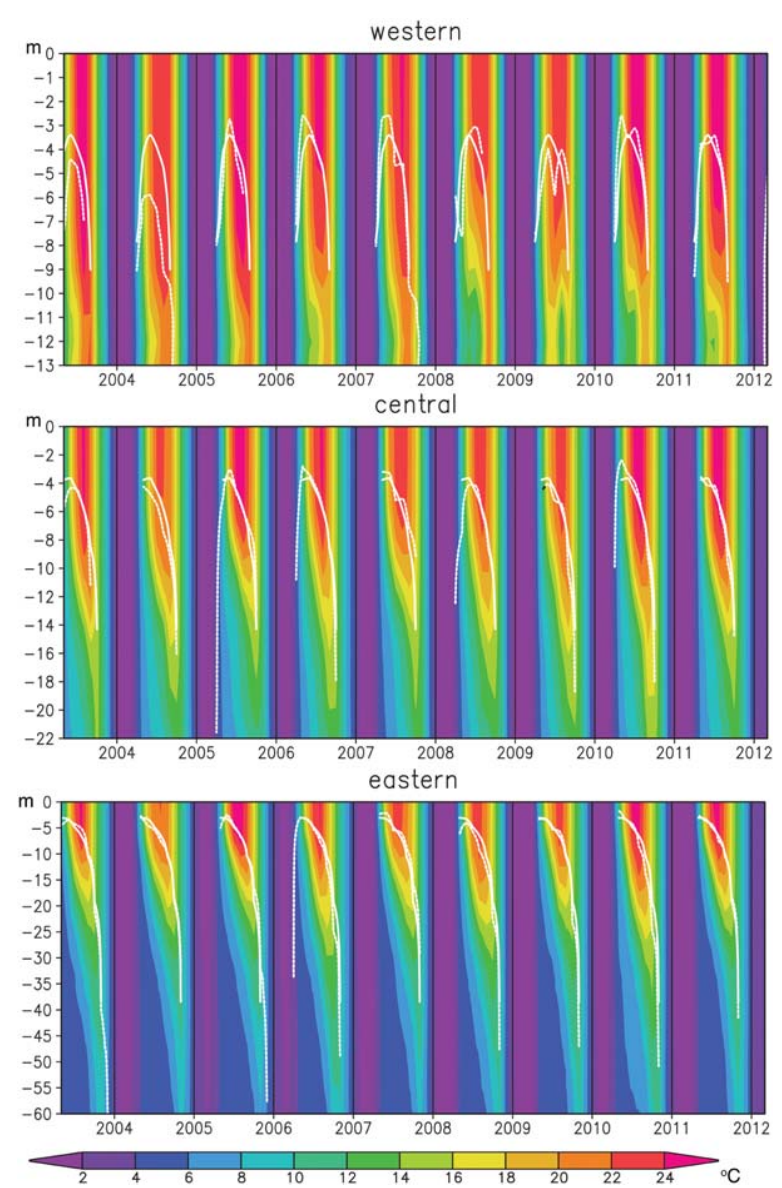

Figure 12. Time series of water temperature profiles in the western, central, and eastern basins shown in Figure 1. Lines denote the depth of the mixed layer, which is defined as the layer where the temperature difference from the surface is less than $0.5^{\circ} \mathrm{C}$ : Solid lines are for the 9 year mean, and dotted lines are for the actual years.

[32] The lake circulation in January to March shows a significant interannual variation in association with ice cover. The packed ice cover can reduce the intensity of the circulation significantly by the ice-water stress coupling [Fujisaki et al., 2012], since packed ice cover reduces wind stress transmitted to the water surface, dampening the surface flow. In the mild winters of 2006 and 2012, the anomalously active circulations were found in January to March. Unlike the other years, the flow kept the active two cell patterns (Figure 16). In the severe winters of 2009 and 2011, the circulations in January to March were weaker, and mostly cyclonic over the lake. Indeed, the wind stresses transmitted to the water surface in the mild winters were anomalously high, while those in the severe winters were significantly reduced. Interestingly, this happened even though our model assumes the air-ice drag coefficient is well above the air-water drag coefficient for wind speed of $0-20 \mathrm{~m} / \mathrm{s}$ (section 2.1). This means that the limited motion of the packed ice cover (i.e., reduced ice velocity) restricted the effectiveness of momentum transfer as was also discussed in Fujisaki et al. [2012].

[33] The model does not take into account the major river discharges. This could alter the flow in the estuaries and shallow waters. We compared the annual mean circulation in 2006 with the model results from Dupont et al. [2012] that include model-simulated river discharges. The eastward coastal flow and relatively weak flow in the offshore region were consistent with each other (not shown). On the other hand, the current speed in the western basin was relatively weak $(<0.01 \mathrm{~m} / \mathrm{s})$ compared with the results by Dupont et al. [2012], possibly related to the exclusion of the river discharge from the Detroit River. However, in terms of winter circulation, the dampening effect by ice cover could be dominant, and further evaluation would be necessary. Note that the year 2006 was characterized by anomalously low ice coverage.

[34] Figure 17 shows the interannual variation of the vertical eddy viscosity. The two peaks of $10^{-2} \mathrm{~m}^{2} / \mathrm{s}$ line are likely due to the fall and spring overturn. The stronger penetration of vertical mixing is observed in the beginning of 2006 and 2012. The less areal fraction of ice cover in those mild winters allowed the wind mixing to penetrate more deeply. The negative anomaly in the winters of 2005 and 2010 are related to the weak wind speed in the two seasons (Figure 18).

[35] The consequences of the increased wind stress, the stronger vertical mixing, and the active circulation in low ice coverage years could influence the surface current speed, the coastal Ekman upwelling or downwelling, lake turbidity in winter-spring, material transports, and so on.
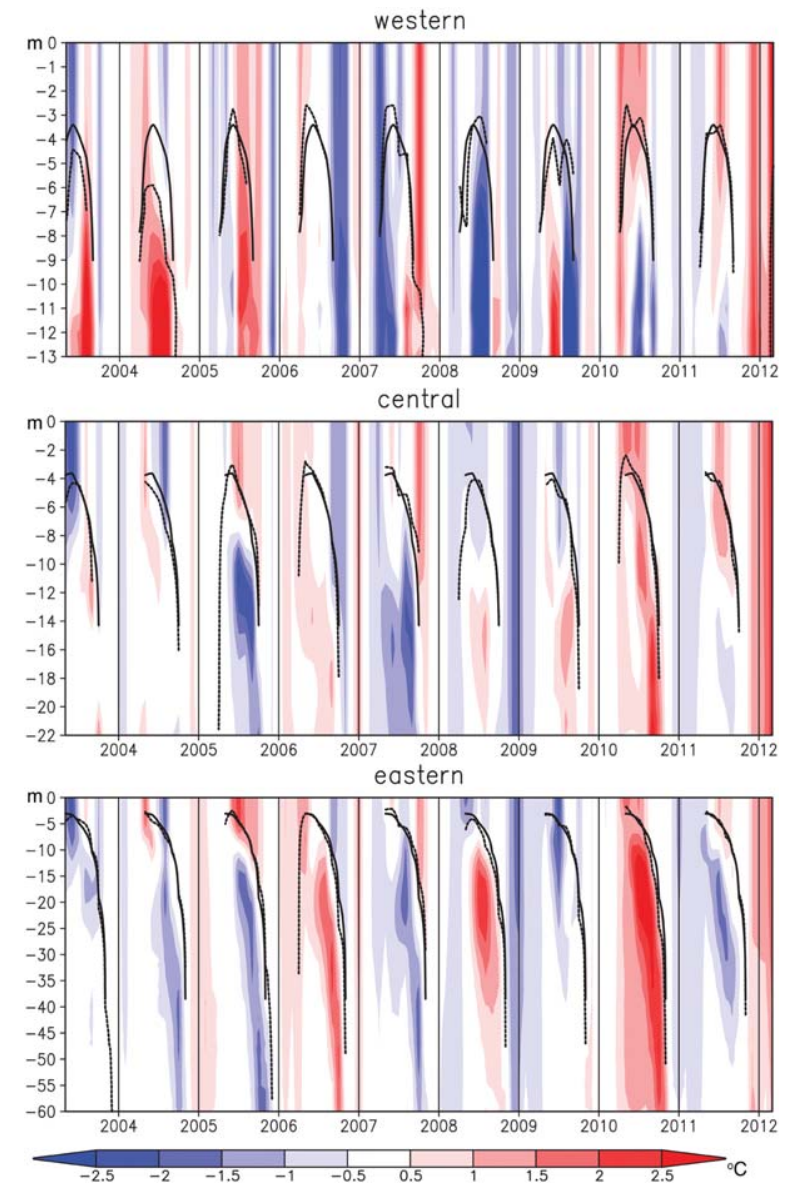

Figure 13. Similar to Figure 12, but the color shows the anomaly from the 9 year mean. 

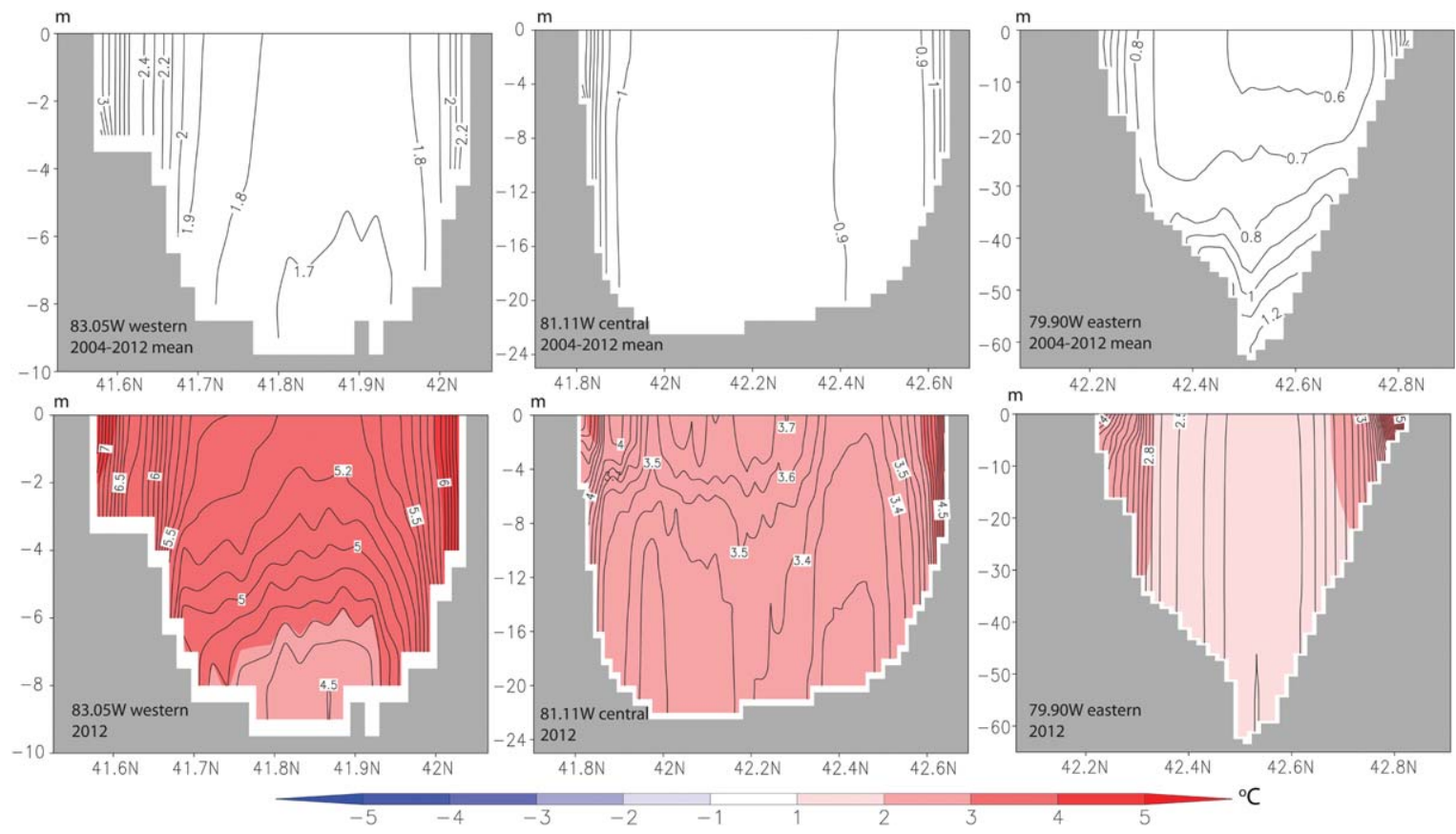

Figure 14. Similar to Figure 10, but for March. (top) The 2004-2012 mean and (bottom) 2012. Contour interval is $0.1^{\circ} \mathrm{C}$.

\section{Interannual Variability in Response to Atmospheric Forcing}

\subsection{Coastal Current Speed in Association With Ice Conditions and Wind}

[36] The impacts of the increase in wind stress on the lake circulation in the mild winters are important.
Figure 18a shows the seasonal means of the coastal current speed over the region shallower than $10 \mathrm{~m}$. The coastal current speed during January to March is significantly high in 2006 and 2012. Such anomalously strong coastal flows are due to less dampening by ice cover in the mild winters. A similar tendency was found in the lake-wide mean current speed, but it was more evident in the coastal current, due to
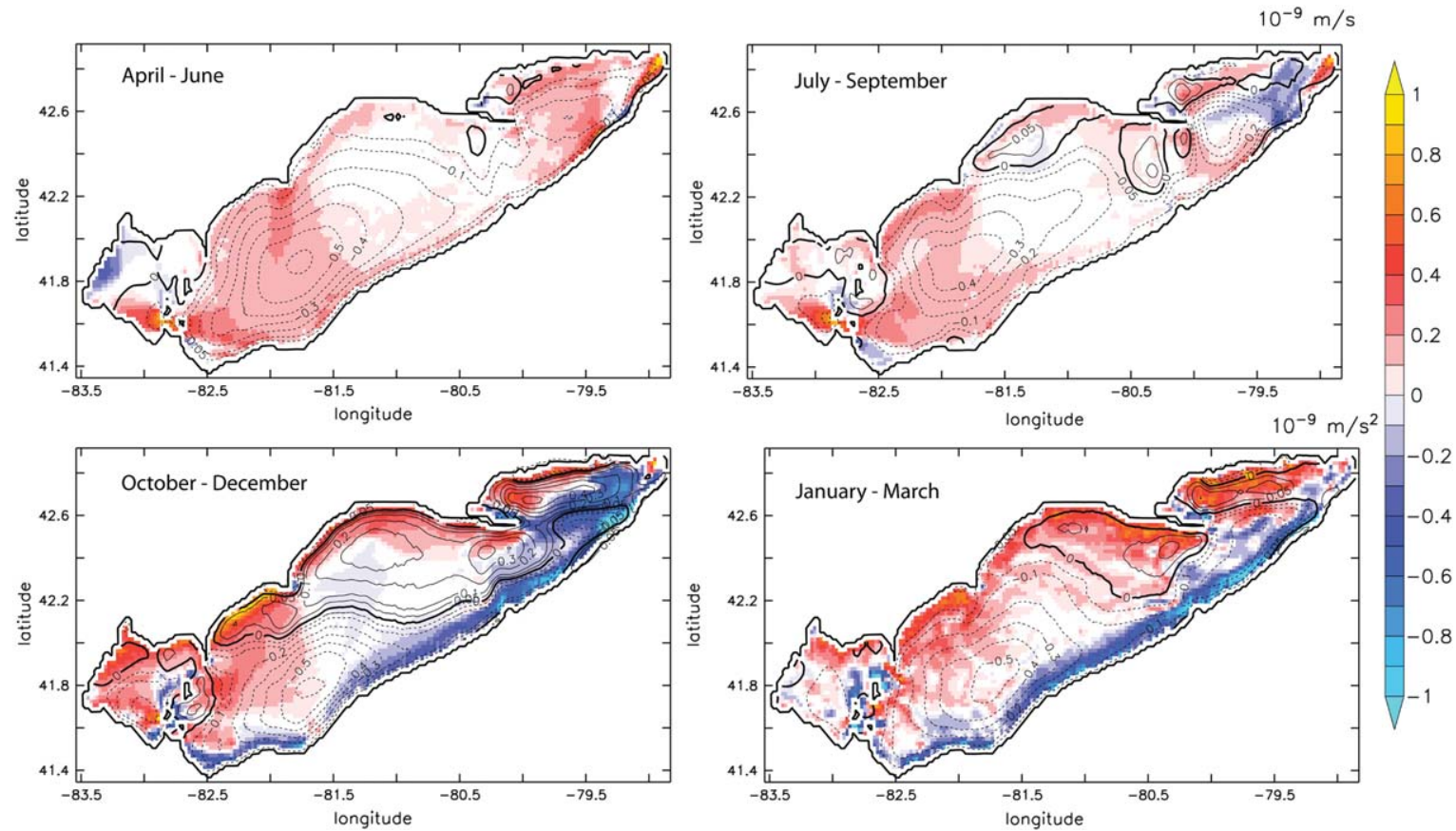

Figure 15. Seasonal means of stream function $\left[0.1 \times 10^{3} \mathrm{~m}^{2} / \mathrm{s}\right]$ (contour) and wind stress curl $\left[10^{-9} \mathrm{~m} / \mathrm{s}^{2}\right]$ (color shade), mean from 18 April 2003 to 17 April 2012. Contour intervals are $0.1 \times 10^{-9} \mathrm{~m} / \mathrm{s}^{2}$, but $\pm 0.05 \times 10^{-9} \mathrm{~m} /$ $\mathrm{s}^{2}$ are also shown. 

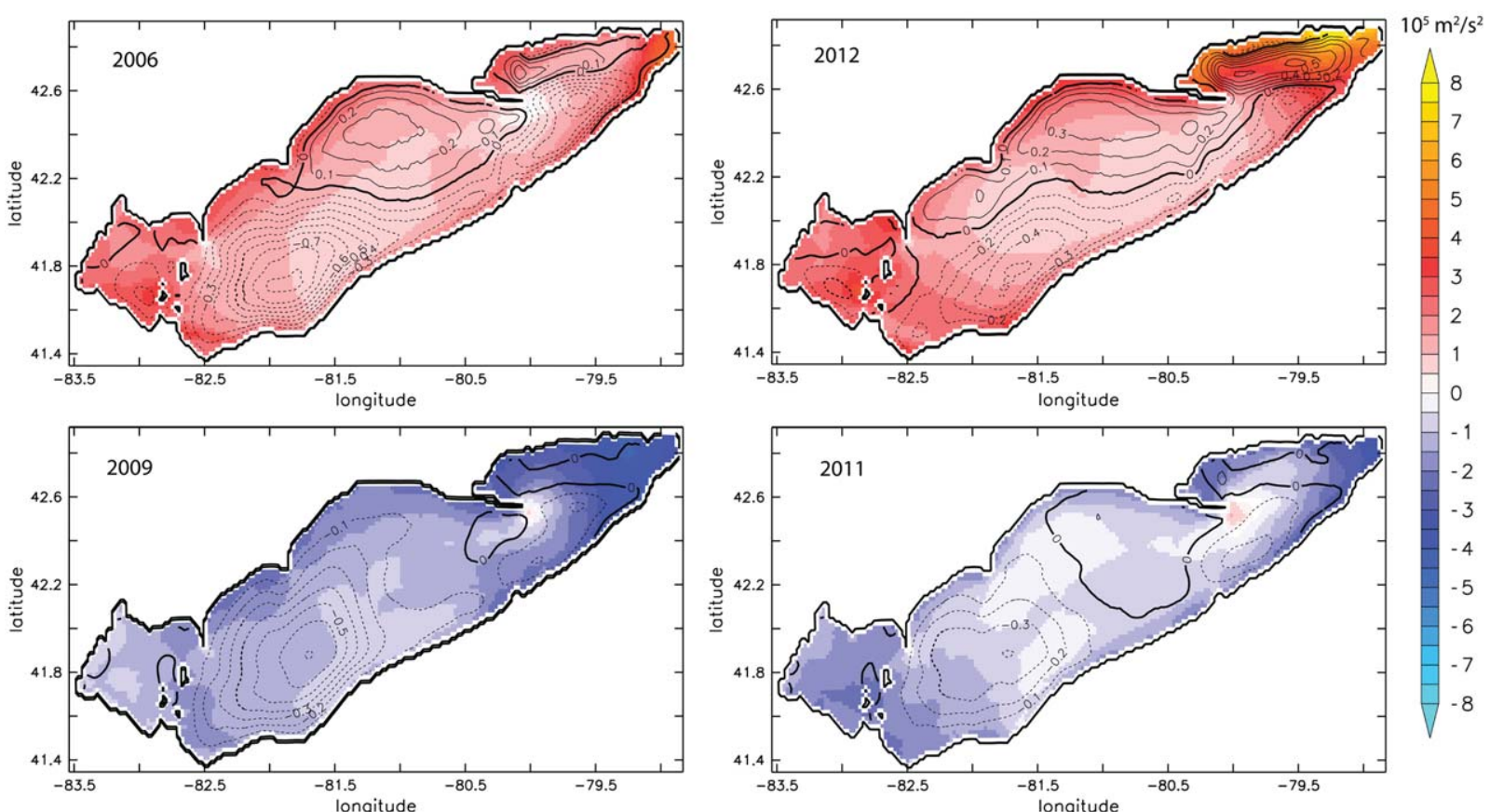

Figure 16. Winter stream functions (January to March) in (top) the mild winters of 2006 and 2012 and (bottom) the severe winters of 2009 and 2011. Contour interval is $0.1 \times 10^{3} \mathrm{~m}^{2} / \mathrm{s}$. Color shading shows the anomaly of the wind stress magnitude from the 2004 to 2012 mean.

the longer ice-covered period in the coastal region. The mean wind speeds in January to March in those two seasons were not particularly strong, being almost the same as the 9 year mean. Hence, this is not due to the interannual variation of mean wind speed, but due to the low ice coverage in the two winters.

[37] On the other hand, the coastal current speed during January to March was anomalously weak in 2009 and 2011 (severe winters). The packed ice condition in these winters prevented wind stress from being transmitted to the water surface, resulting in the slowed lake circulations. It is likely that both wind speed and ice condition could influence the current speed in winter. The winter of 2007 showed stronger coastal current speed than those of 2009 and 2011, in spite of the similar production of ice (Figure 3). This is due to the strong wind speed over the lake in January to March of 2007 (Figure 18b). Likewise, the weak coastal current in the same period of 2010 was likely influenced by the weak wind speed over the lake, as the ice production in the season was about the same as the 9 year mean (Figure 2a).

[38] The year-to-year fluctuating coastal current speed in January to March contrasts with weak seasonal fluctuations in the other seasons (Figure 18a). There are weak negative trends in the coastal current speed from -0.06 to -0.02 $\mathrm{cm} / \mathrm{s}$ per year over the 9 years, except for April to June (not shown). They are likely associated with the weak negative trend in wind speed over the lake that ranged from -0.07 to $-0.02 \mathrm{~m} / \mathrm{s}$ per year. A weakening wind was also observed in Lake Ontario throughout the seasons over the past 40 years [Huang et al., 2012]. On the other hand, summer wind speed over Lake Superior has increased since 1985 [Desai et al., 2009]. These opposing findings could be because of the differences in the areas of ice cover between the two lakes. Desai et al. [2009] ascribed the increase in summer wind speed to the faster melting of ice in Lake Superior, which caused the earlier onset of stratification and reduced the air-water temperature gradient, destabilizing the boundary layer and resulting in the increased wind speed. In Lake Ontario, the areal fraction of ice is much smaller than that in Lake Superior (maximum $85 \%$ in Lake Superior and $15 \%$ in Lake Ontario, mean through 19792011, Wang et al. [2012b]). While the long-term decrease in ice cover is reported in all the Great Lakes [Wang et al., 2012a, 2012b], the preexisting small fraction of ice in Lake Ontario may not influence the surface warming in springsummer. Our study period for Lake Erie is much shorter than the previous studies for Lake Superior or Lake Ontario, and is not enough to conclude whether or not a similar process has occurred. Given the high ice coverage in Lake Erie, it is possible that an earlier melting of ice can influence the spring-summer warming if the time scale is expanded to several decades. This point deserves future study.

[39] One notable feature is that the interannual variation in coastal current speed during winter ranged from $3.9 \mathrm{~cm} / \mathrm{s}$ in the severe winter of 2009 to $7.2 \mathrm{~cm} / \mathrm{s}$ in the mild winter of 2012, and the accelerations of the coastal current during the low ice cover years are $+1.6 \mathrm{~cm} / \mathrm{s}(2006)$ and $+1.9 \mathrm{~cm} /$ s (2012), more than $30 \%$ of the 9 year mean, which is much larger than the interannual variation within $\pm 0.6 \mathrm{~cm} /$ $\mathrm{s}$ in the other seasons.

[40] These results indicate that the coastal current during winter could become stronger in the longer time scale if ice cover in the Great Lakes continues to decline in the future [Wang et al., 2012a]. An increase of the coastal current under low ice cover conditions could influence material transport, such as nutrient loads from the coast, which would affect plankton blooms in the following spring and 

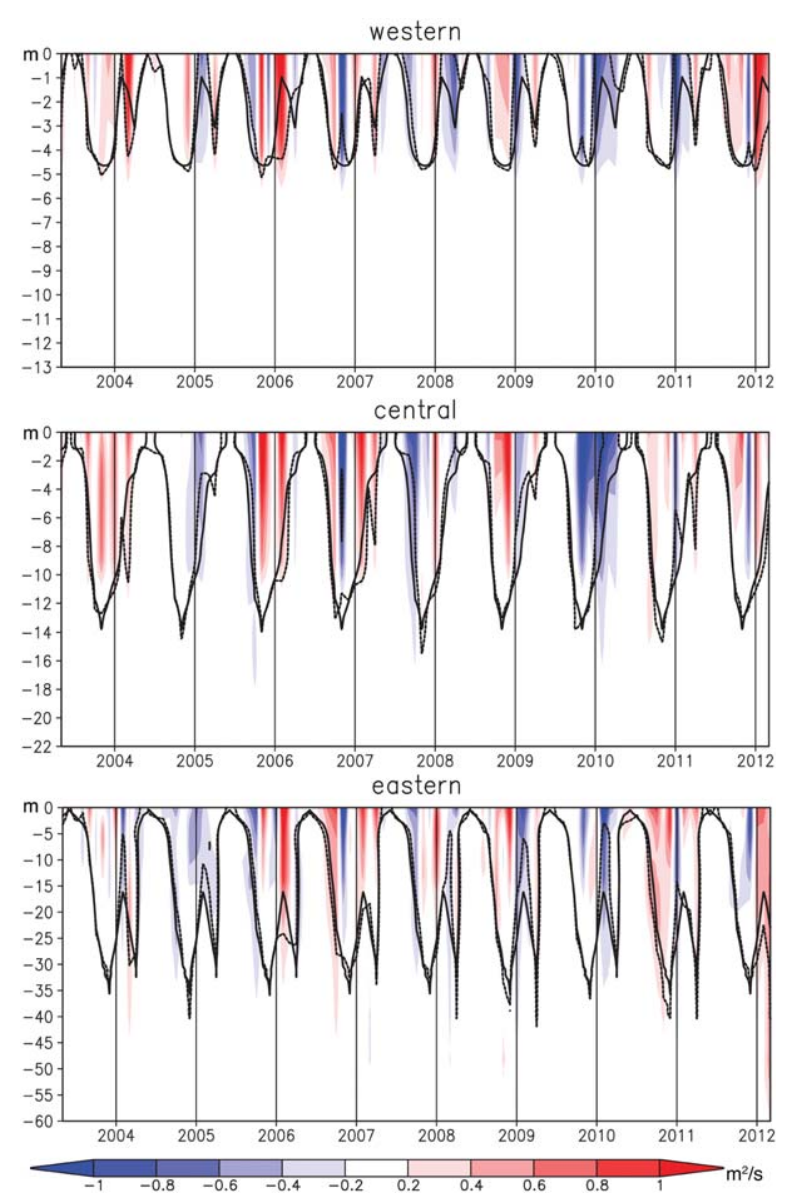

Figure 17. Time series of the vertical eddy viscosity profile in the western, central, and eastern basins shown in Figure 1. Colors show the anomalies of the vertical eddy viscosity $\left(10^{-2} \mathrm{~m}^{2} / \mathrm{s}\right)$ from the 9 year mean. Lines denote the contour of $10^{-2} \mathrm{~m}^{2} / \mathrm{s}$ : Solid lines are for the 9 year mean, and dotted lines are for the actual years.

summer. However, the link would not be simple because, while the increased coastal current speed during winter in the mild winters can transport nutrient loads offshore more effectively, and the warm temperature is also favorable for plankton blooms, the strong wind stress also causes stronger vertical mixing (Figure 17), which results in higher turbidity (not favorable for photosynthesis). Our model does not couple the lake ecosystem, and evaluating impacts on the ecosystem are beyond our scope.

\subsection{Relationship With Climate Teleconnection Patterns}

[41] On interannual time scales, the natural variability is more dominant in determining ice conditions. As the strong correlation between ice production and cumulative freezing degree days showed, ice conditions are closely tied to the local surface air temperatures, which can be related to the large-scale climate events. Low ice cover in the Great Lakes is likely related to strong El Niño events or La Niña with a positive NAO event, while high ice coverage is often related to a negative NAO event [Bai et al., 2012].

[42] The winters of 2006 and 2012 had Great Lakes ice cover that was anomalously low, even when the compari- son period was expanded to the last four decades [Bai et al., 2012], rather than just our simulation period. The ice minimum in the winter of 2012 was explained by a combination of La Niña and a positive NAO event throughout the winter (X. Bai, personal communication, 2013). They also identified below-normal ice coverage in the six out of seven La Niña and positive NAO winters since 1973. On the other hand, the winter of 2006 was a La Niña event, but the NAO index averaged from December to March was negative, which was favorable for a cold winter. Even though the winter-mean NAO index was negative, an intermittent positive NAO event occurred in January (December: -0.4 , January: 1.3, February: -0.5 , March: -1.3 , mean: -0.2 , data are taken from the monthly mean NAO index since January 1950 by NOAA/Climate Prediction Center). A strong positive anomaly of air temperature covered the Great Lakes region in January 2006, while the air temperature in the other months was around the normal (Figure 19). The mean air temperature over Lake Erie in January was about $2^{\circ} \mathrm{C}$ higher than the 9 year mean (Figure 2). The pattern of $500 \mathrm{hPa}$ height in January 2006 was characterized by the combined effects of a positive phase of NAO and La Niña, with the positive anomaly over the Great Lakes region, preventing the cold air from coming down from the Arctic (Figure 20). The feature disappeared if the pattern was averaged through the winter (December to
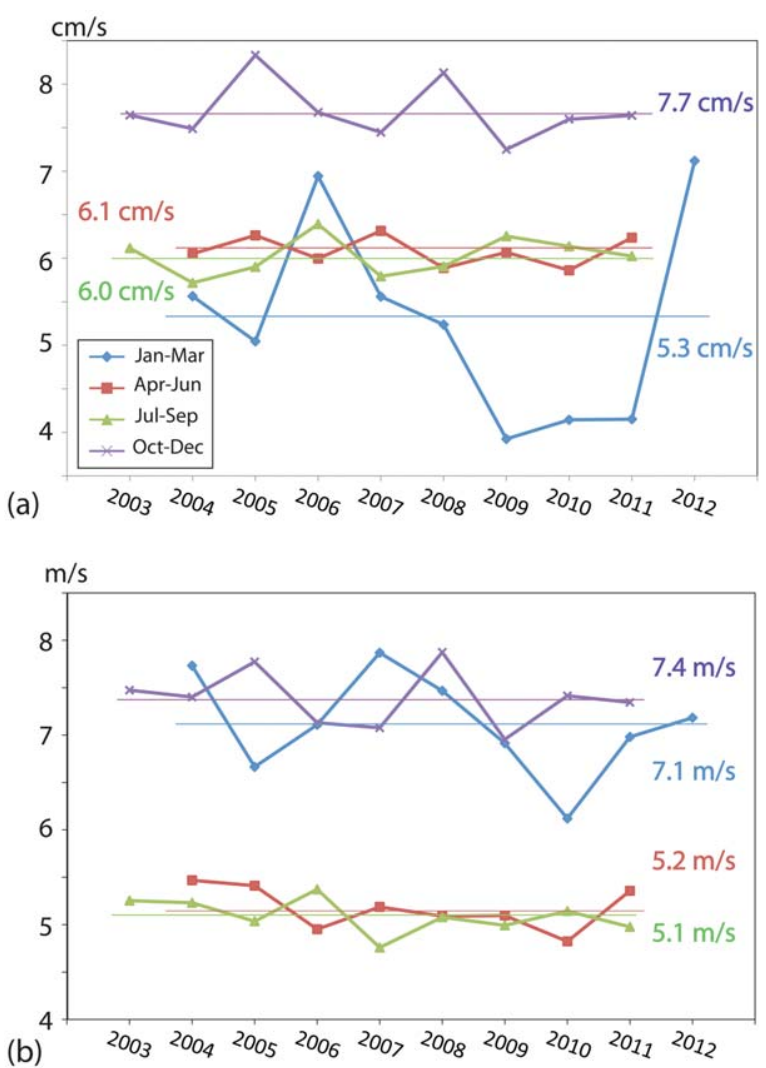

Figure 18. Seasonal means of (a) coastal current speed and (b) wind speed over Lake Erie from 2003 to 2011 (2004-2011 for April to June and 2004-2012 for January to March). The coastal current speed is the mean over the region with the depth less than $10 \mathrm{~m}$. Color lines with numbers denote the mean values over the 8 or 9 years. 

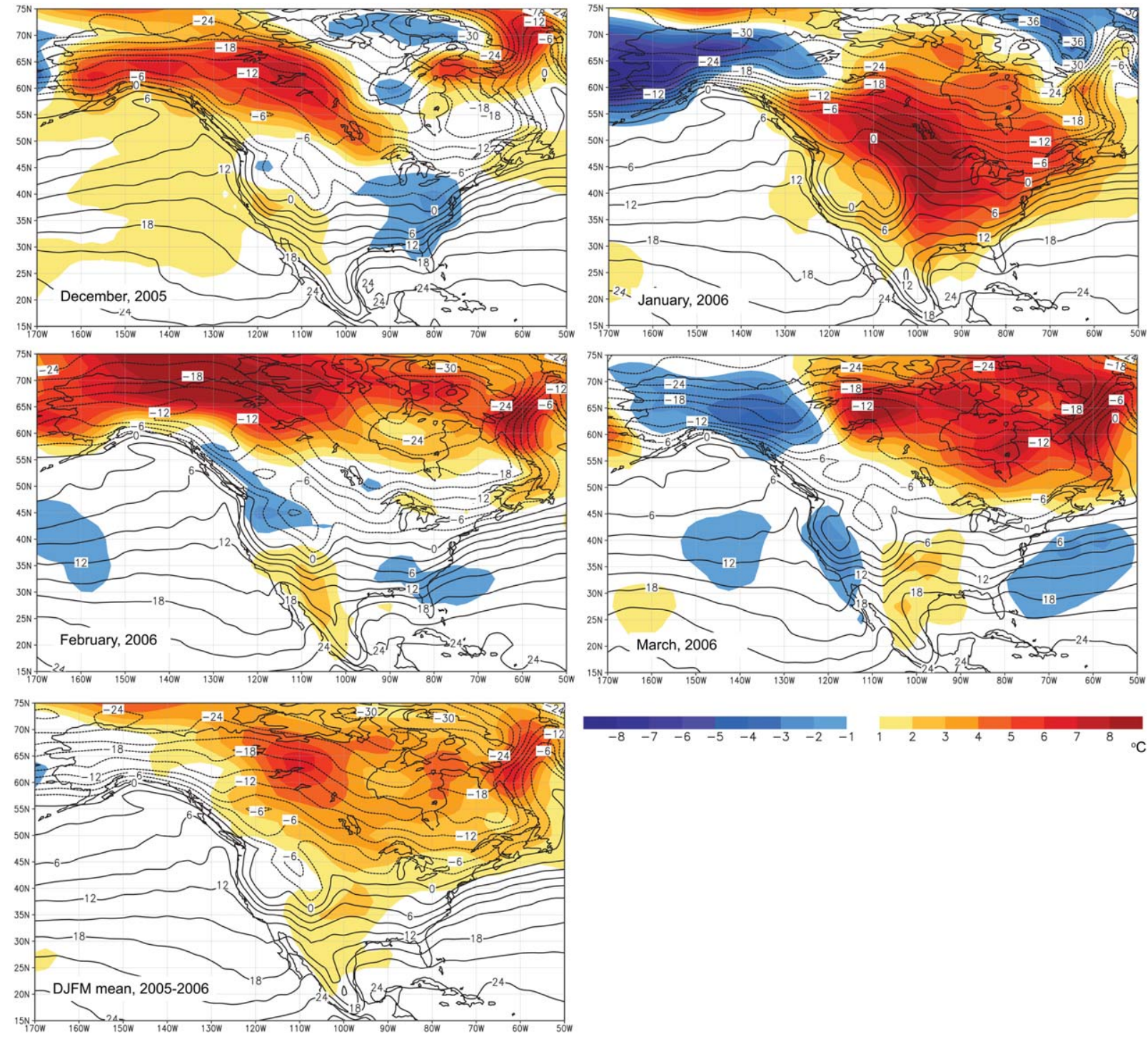

Figure 19. Surface air temperature (contour) and anomaly (color) in the winter of 2006. Monthly mean from December 2005 to March 2006, and mean through December 2005 to March 2006. The reanalysis data set from the National Centers for Environmental Prediction/National Center for Atmospheric Research is used. Anomaly is the deviation from the climatology from 1948 to 2010.

March). Such an intermittent positive anomaly over the Great Lakes likely prevented cooling of the lake such that the low ice cover occurred in the winter of 2006.

[43] A similar explanation could be possible for the severe winter of 2009. The severe winter of 2011 occurred in a significantly negative NAO event with La Niña (State 4 of Bai et al. [2012]; see their Table 2). On the other hand, the ENSO and NAO in the winter of 2009 were almost neutral. Monthly breakdowns show negative NAO indexes in December and January (December: -0.3 , January: -0.01 , February: 0.06, March: 0.6, mean: 0.09), and the monthly Niño 3.4 anomaly taken from the NOAA/Climate Prediction Center shows relatively strong negative anomaly in the 2 months (December: -0.8 , January: -1 , February: -0.7 , March: -0.6 , mean: -0.8$)$. The severe ice condition likely occurred in this intermittent negative NAO with La Niña event. For the shallow basins with low heat capacity like Lake Erie, it may be potentially useful to observe the relationship with teleconnection patterns at the time scale of a month or less.

\section{Summary and Conclusions}

[44] A three-dimensional ice-hydrodynamic model was used to simulate the ice circulation of Lake Erie for nine winters from 2003 to 2012. Analysis focused on the severe winters of 2009 and 2011 and the mild winters of 2006 and 2012. Based on the above investigation, the following conclusions can be drawn:

[45] 1. The model reasonably reproduced ice area, lake surface temperature, and lake circulation. The model also reproduced ice thickness field comparable to the in situ observations, while ice thickness in the eastern basin was overestimated. The simulated volumetric production of ice was strongly correlated with the cumulative freezing degree days. 

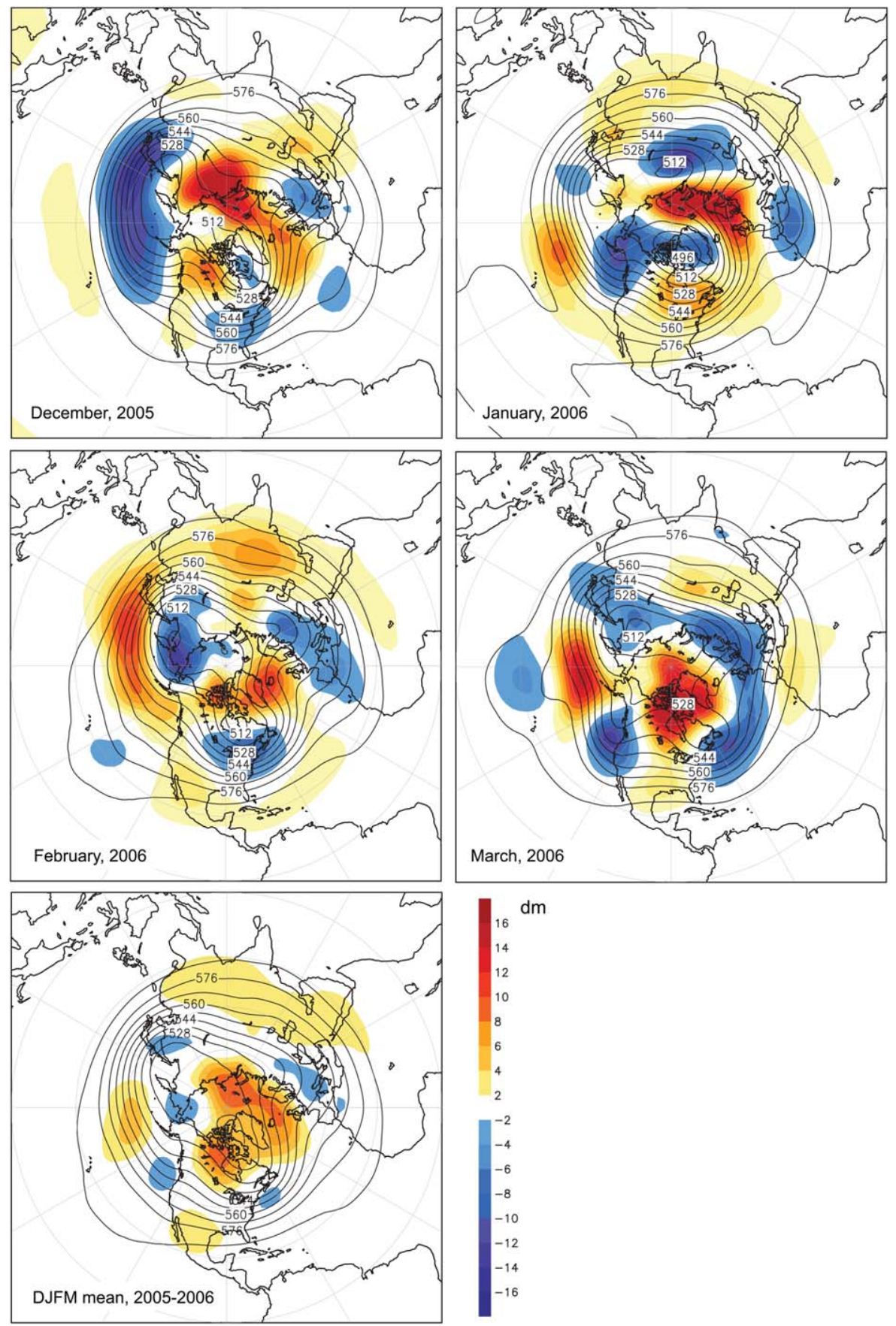

Figure 20. Similar to Figure 19, but for $500 \mathrm{hPa}$ height (contour) and anomaly (color). Units are in decimeters.

[46] 2. Thermal structure in summer was characterized by stratification, except for the shallow western basin. In winter, the thermal structure was relatively homogeneous due to both cooling and wind mixing. In the deepest region of the eastern basin, the lower layer was stratified, and the relatively warm hypolimnion remained, which was destroyed in the following spring overturn. In the record warm winter of 2012, the thermal structure in March showed an unusually early onset of stratification in the western and central basins, which was due to the warm air as well as little ice cover in the lake.
[47] 3. The model results show that ice cover significantly influences lake circulation in winter. In the mild winters of 2006 and 2012, the lake circulation in winter (January to March) is significantly more active than the 9 year mean. The larger open water area in the mild winters allowed winds to drive lake circulation more effectively, while the packed ice cover and the associated limited motion of ice in the severe winters reduced the wind stress transmitted to the water surface and slowed down the surface current. The deeper penetration of the strong vertical eddy viscosity was also found in the mild winters. The 
interannual variation in coastal current speed during winter ranged from $3.9 \mathrm{~cm} / \mathrm{s}$ in the severe winter of 2009 to 7.2 $\mathrm{cm} / \mathrm{s}$ in the mild winter of 2012, while the variation in the other seasons was no more than $0.6 \mathrm{~cm} / \mathrm{s}$ from the 9 year means. This accelerated coastal current in the mild winters implies that decreasing ice cover in the Great Lakes could lead to a more energetic coastal current during winter due to the larger input of wind stress, resulting in changing material transport, nearshore waves, and ecology.

[48] We also discussed the characteristic severe and mild winters and the anomalous ice conditions in conjunction with ENSO and NAO events, based on Bai et al. [2012]. While the low ice cover in 2012 was consistent with La Niña and the positive NAO event in the winter, the low ice cover in the winter of 2006 was likely caused by the intermittent negative NAO event in January and the La Niña condition, as the winter average of NAO index was negative, which is favorable for high ice coverage. Similarly, the severe winter of 2009 and its high ice coverage were likely caused by the intermittent negative NAO in December.

[49] Our study indicates the large interannual variability of ice cover could cause significant variability in lake circulation as well as thermal structure, not only in Lake Erie but also in the other four lakes. Further modeling studies that cover the entire Great Lakes will be useful to assess the ice-water coupling in the Great Lakes. The relation of the Great Lakes ice cover to the teleconnection patterns appears to be complicated, but it would be useful to advance the knowledge as the consequences would not be limited to anomalous ice cover but could influence the subjacent lake physics.

[50] Acknowledgments. The paper is supported by the EPA Great Lakes Restoration Initiative (GLRI), and NSF OCE grant 0927643.We would like to thank David J. Schwab for providing the meteorological data, Dmitry Beletsky for helpful discussion, and the two anonymous reviewers for their comments. Thanks also to Cathy Darnell of GLERL for editing this paper. This is GLERL contribution 1670.

\section{References}

Assel, R. A., S. Drobrot, and T. E. Croley (2004), Improving 30-day Great Lakes ice cover outlooks, J. Hydrometeorol., 5, 713-717.

Austin, J. A., and S. M. Colman (2007), Lake Superior summer water temperatures are increasing more rapidly than regional air temperatures: A positive ice-albedo feedback, Geophys. Res. Lett., 34, L06604, doi:10.1029/2006GL029021.

Bai, X., J. Wang, Q. Liu, D. Wang, and Y. Liu (2011), Severe ice conditions in the Bohai Sea, China and mild ice conditions in the Great Lakes during the 2009/10 winter: Links to El Niño and a strong negative arctic oscillation, J. Appl. Meteorol. Clim., 50, 1922-1935, doi:10.1175/ 2011JAMC2675.1.

Bai, X., J. Wang, C. Sellinger, A. Clites, and R. A. Assel (2012), Interannual variability of Great Lakes ice cover and its relationship to NAO and ENSO, J. Geophys. Res., 117, C03002, doi:10.1029/2010JC006932.

Bai, X., J. Wang, D. J. Schwab, Y. Yang, L. Luo, G. A. Leshkevich, and S. Liu (2013), Modeling 1993-2008 climatology of seasonal general circulation and thermal structure in the Great Lakes using FVCOM, Ocean Modell., 65, 40-63, doi:10.1016/j.ocemod.2013.02.003.

Beletsky, D., and D. J. Schwab (2001), Modeling circulation and thermal structure in Lake Michigan: Annual cycle and interannual variability, $J$. Geophys. Res., 106(C9), 19,745-19,771.

Beletsky, D., J. H. Saylor, and D. J. Schwab (1999), Mean circulation in the Great Lakes, J. Great Lakes Res., 25(1), 78-93.

Beletsky, D., D. J. Schwab, P. J. Roebber, and M. J. McCormick (2003), Modeling wind-driven circulation during the March 1998 sediment resuspension event in Lake Michigan, J. Geophys. Res., 108(C2), 3038, doi:10.1029/2001JC001159.

Beletsky, D., N. Hawley, Y. R. Rao, H. A. Vanderploeg, R. Beletsky, D. J. Schwab, and S. A. Ruberg (2012), Summer thermal structure and anticyclonic circulation of Lake Erie, Geophys. Res. Lett., 39, L06605, doi:10.1029/2012GL51002.

Bennett, J. R. (1974), On the dynamics of wind-driven lake currents, $J$. Phys. Oceanogr., 4, 400-414.

Bennington, V., G. A. Mckinley, N. Kimura, and C. H. Wu (2010), General circulation of Lake Superior: Mean, variability, and trends from 1979 to 2006, J. Geophys. Res., 115, C12015, doi:10.1029/2010JC006261.

Bolsenga, S. J. (1988), Nearshore Great Lakes ice cover, Cold Reg. Sci. Technol., 15, 99-105, doi:10.1016/0165-232X(88)90057-2.

Craig, P. D., and M. L. Banner (1994), Modeling wave-enhanced turbulence in the ocean surface layer, J. Phys. Oceanogr., 24, 2546-2559.

Desai, A. R., J. A. Austin, V. Bennington, and G. A. McKinley (2009), Stronger winds over a large lake in response to weakening air-to-lake temperature gradient, Nat. Geosci., 2, 855-858, doi:10.1038/NGEO693.

Dupont, F., P. Chittibabu, V. Fortin, Y. R. Rao, and Y. Lu (2012), Assessment of a NEMO-based hydrodynamic modeling system for the Great Lakes, Water Qual. Res. J. Can., 47(3-4), 198-214, doi:10.2166/ wqrjc. 2012.014.

Emery, K. O., and G. T. Csanady (1973), Surface circulation of lakes and nearly land-locked seas, Proc. Natl. Acad. Sci. U. S. A., 70(1), 93-97.

Fujisaki, A., J. Wang, D. J. Schwab, H. Hu, N. Hawley, and Y. R. Rao (2012), A modeling study of ice-water processes for Lake Erie, J. Great Lakes Res., 38, 585-599, doi:10.1016/j.jglr.2012.09.021.

Gerbush, M. R., D. A. R. Kristovich, and N. F. Laird (2008), Mesoscale boundary layer heat flux variations over pack ice-covered Lake Erie, $J$. Appl. Meteorol. Climatol., 47, 668-682.

Hibler, W. D. (1979), Dynamic thermodynamic sea ice model, J. Phys. Oceanogr., 9(4), 815-846.

Hu, H., and J. Wang (2010), Modeling effects of tidal and wave mixing on circulation and thermohaline structures in the Bering Sea: Process studies, J. Geophys. Res., 115, C01006, doi: 10.1029/2008JC005175.

Huang, A., Y. R. Rao, and W. Zhang (2012), On recent trends in atmospheric and limnological variables in Lake Ontario, J. Clim., 25, 58075816, doi:10.1175/JCLI-D-11-00495.1.

Hunke, E. C., and J. K. Duckowicz (1997), An elastic-viscous-plastic model for sea ice dynamics, J. Phys. Oceanogr., 27, 1849-1867, doi:10.1175/1520-0485(1997)027<1849:AEVPMF>2.0.CO;2.

Kerfoot, W. C., F. Yousef, S. A. Green, J. W. Budd, D. J. Schwab, and H. A. Vanderploeg (2011), Approaching storm: Disappearing winter bloom in Lake Michigan, J. Great Lakes Res., 36, 30-41.

Leon, L. F., J. Imberger, R. E. H. Smith, R. E. Hecky, D. Lam, and W. Schertzer (2005), Modeling as a tool for nutrient management in Lake Erie: A hydrodynamics study, J. Great Lakes Res., 31, 309-318.

Liu, P. C., and D. J. Schwab (1987), A comparison of methods for estimating $\mathrm{u} *$ from given u $\mathrm{z}$ and air-sea temperature differences, J. Geophys. Res., 92(C6), 6488-6494, doi:10.1029/JC092iC06p06488.

Luo, L., J. Wang, D. Schwab, H. A. Vanderploeg, G. Leshkevich, X. Bai, H. Hu, and D. Wang (2012), Simulating the 1998 spring bloom in Lake Michigan using a coupled physical-biological model, J. Geophys. Res., 117, C10011, doi :10.1029/2012JC008216.

Magnuson, J. J. et al. (2000), Historical trends in lake and river ice in the Northern Hemisphere, Science, 289, 1743-1746.

Mellor, G., S. Hakkinen, T. Ezer, and R. Patchen (2002), A generalization of a sigma coordinate ocean model and an intercomparison of model vertical grids, in Ocean Forecasting: Conceptual Basis and Applications, edited by N. Pinardi and J. D. Woods, pp. 55-72, Springer, Berlin.

Mellor, G. L., and T. Yamada (1982), Development of a turbulence closure model for geophysical fluid problems, Rev. Geophys., 20(4), 851-875.

Niimi, A. J. (1982), Economic and environmental issues of the proposed extension of the winter navigation season and improvements on the Great Lakes-St. Lawrence Seaway system, J. Great Lakes Res., 8, 532-549.

Notaro, M., K. Holman, A. Zarrin, E. Fluck, S. Vavrus, and V. Bennington (2013), Influence of the Laurentian Great Lakes on regional climate, $J$. Clim., 26, 789-804, doi:http://dx.doi.org/10.1175/JCLI-D-12-00140.1.

Parkinson, C. L., and W. M. Washington (1979), A large-scale numerical model of sea ice, J. Geophys. Res., 84(C1), 311-337.

Saylor, J. H., and G. S. Miller (1987), Studies of large-scale currents in Lake Erie, 1979-80, J. Great Lakes Res., 13(4), 487-514.

Schertzer, W. M., J. H. Saylor, F. M. Boyce, D. G. Robertson, and F. Rosa (1987), Seasonal thermal cycle of Lake Erie, J. Great Lakes Res., 14(4), $468-486$. 
Schwab, D. J., and K. W. Bedford (1999), The Great Lakes forecasting system, coastal and estuarine studies, Coastal Ocean Predict., 56, 157-173, doi: 10.1029/CE056p0157.

Schwab, D. J., and D. Beletsky (2003), Relative effects of wind stress curl, topography, and stratification on large-scale circulation in Lake Michigan, J. Geophys. Res., 108(C2), 3044, doi:10.1029/2001JC001066,2003.

Schwab, D. J., D. Beletsky, J. Depinto, and D. M. Dolan (2009), A hydrodynamic approach to modeling phosphorus distribution in Lake Erie, $J$. Great Lakes Res., 35, 50-60.

Semtner, A. J. (1976), A model for the thermodynamic growth of sea ice in numerical investigations of climate, J. Phys. Oceanogr., 6, 379-389, doi:10.1175/1520-0485(1976)006<0379:AMFTTG>2.0.CO;2.

Thorndike, A. S., D. A. Rothrock, G. A. Maykut, and R. Colony (1975), The thickness distribution of Sea Ice, J. Geophys. Res. 80(33), 45014513.

Vanderploeg, H. A., S. J. Bolsenga, G. L. Fahnenstiel, J. R. Liebig, and W. S. Gardner (1992), Plankton ecology in an ice-covered bay of Lake Michigan: Utilization of a winter phytoplankton bloom by reproducing copepods, Hydrobiologia, 243/244, 175-198.

Wadhams, P. (2002), Ice in the Ocean, Gordon and Breach, Amsterdam.
Wang, J. (1996), Global linear stability of the two-dimensional shallowwater equations: Application of the distributive theorem of roots for polynomials on the unit circle, Mon. Weather Rev., 124(6), 1301-1310.

Wang, J., X. Bai, G. A. Leshkevich, M. Colton, A. Clites, and B. Lofgren (2010a), Severe ice cover on Great Lakes during winter 2008-2009, Eos Trans. $A G U, 91(5), 41-42$.

Wang, J., H. Hu, D. J. Schwab, G. A. Leshkevich, D. Beletsky, N. Hawley, and A. Clites (2010b), Development of the Great Lakes Ice-circulation Model (GLIM): Application to Lake Erie in 2003-2004, J. Great Lakes Res., 36, 425-436.

Wang, J., X. Bai, H. Hu, A. Clites, M. Colton, and B. Lofgren (2012a), Temporal and spatial variability of Great Lakes ice cover, 1973-2010, J. Clim., 25, 1318-1329, doi:10.1175/2011JCLI4066.1.

Wang, J., R. A. Assel, S. Walterscheid, A. Clites, and X. Bai (2012b), Great lakes ice climatology update: Winter 2006-2011 description of the digital ice cover data set, NOAA Tech. Memor. GLERL-155, pp. 37, NOAA Great Lakes Environmental Research Laboratory, Ann Arbor, MI. [Available at http://www.glerl.noaa.gov/data/pgs/glice/glice.html.]

White, B., J. Austin, and K. Matsumoto (2012), A three dimensional model of Lake Superior with ice and biogeochemistry, J. Great Lakes Res., 30(1), 61-71. 